\title{
STUDIES OF COPROPORPHYRIN. IV. THE PER DIEM EXCRETION AND ISOMER DISTRIBUTION IN THE URINE IN INFECTIOUS HEPATITIS, INFECTIOUS MONONUCLEOSIS, AND MECHANICAL JAUNDICE ${ }^{1}$
}

\author{
By CECIL JAMES WATSON, VIOLET HAWKINSON, RICHARD B. CAPPS, ${ }^{2}$ \\ AND EMANUEL M. RAPPAPORT 3
} (From the Department of Medicine, University of Minnesota Hospitals, Minneapolis, and the
DeWitt and Schick U. S. Army General Hospitals ${ }^{4}$ )

(Received for publication December 29, 1948)

The occurrence of increased amounts of porphyrin in the urine in cases of liver disease was first duly emphasized by Archibald Garrod $(1,2)$. Garrod believed this to be hematoporphyrin, a confusion with coproporphyrin which was corrected by $H$. Fischer and Zerweck (3), and which undoubtedly depended upon the very close similarity of the absorption spectra of the two porphyrins. When examined with the relatively crude spectroscopes available at the time of Garrod's study, these porphyrins were indistinguishable. The investigations of $\mathrm{H}$. Fischer, however, made it clear that hematoporphyrin does not occur in the urine, if, indeed, it occurs as a natural product at all. Studies of urinary porphyrin excretion in liver disease, subsequent to that of Garrod, have been for the most part of rather fragmentary nature, consisting of one or not more than a few examples of any one affection. The pertinent literature has been reviewed within recent years $(4,5)$ and need not be considered here. Attention may be drawn, however, to the papers of Nesbitt and Snell $(6,7)$ and Localio and co-workers $(8)$, in which considerable data were reported on the fecesurine ratio of coproporphyrin both in obstructive jaundice and liver disease. The papers of Watson $(9,10)$ and Dobriner $(11)$ present limited data on

\footnotetext{
1 Aided by grants from the John and Mary R. Markle Foundation, New York City; the Division of Research Grants and Fellowships, U. S. Public Health Service (Research Grant No. 345) ; and the Medical Research Fund of the Graduate School, University of Minnesota, Minneapolis.

${ }^{2}$ Formerly Chief of Medical Service, DeWitt General Hospital, U. S. A. Present address : 122 South Michigan Avenue, Chicago, Illinois.

${ }^{3}$ Formerly Chief of Gastrointestinal Service, Schick General Hospital, U. S. A. Present address: 148 89th Avenue, Jamaica, New York.

4 Formerly at Auburn, California, and Clinton, Iowa, respectively.
}

the urinary isomer distribution (ratio of types I and III) in these conditions. Dobriner made several important observations in cases of catarrhal jaundice, obstructive jaundice, and cirrhosis of the liver, to which reference will be made again, in this and subsequent papers of this series. Studies of isomer distribution have been generally discouraged, however, by the lack of a method of isomer analysis applicable to small volumes of urine, and as a corollary of this, the lack of exact knowledge of the isomer distribution in normal urine. In previous papers a suitable method has been described $(12,13)$ and in paper I of this series (14) the results of the application of this method to normal urine have been given. The purpose of the present investigation was to determine the total urinary coproporphyrin (UCP) as well as the isomer distribution in 24-hour samples from cases of infectious hepatitis at various stages of the disease, and also, for purposes of comparison, from cases of infectious mononucleosis and of mechanical jaundice, the latter term being used to designate jaundice due to extrahepatic biliary obstruction, or obstruction of the main hepatic ducts in the liver. It was also desired to assay the value of the UCP determination, relative to other methods of studying liver function, as an indication of residual hepatic functional impairment in cases of hepatitis at various periods after the disappearance of jaundice.

\section{MATERIAL AND METHODS}

The method of Schwartz and associates (13) was used to determine the UCP and the isomer distribution. Recent evidence indicates that the true value for the UCP is approximately 20 per cent higher than that obtained with this technique. Nevertheless, all of the data given in the following may be compared directly with the normal data given in paper I (14).

The fractional serum bilirubin was determined according to the modification of the Malloy-Evelyn method 
described by Ducci and Watson (15). The bromsulfalein retention in the blood was determined according to Mateer (16), 45 minutes after injection of $5 \mathrm{mg}$. of the dye per kilo of body weight. The cephalin cholesterol flocculation test was performed according to Hanger (17). Cholesterol and cholesterol esters were determined by the method of Sperry and Schoenheimer (18). In some instances the urine urobilinogen was determined in 24-hour urine samples (19); in others the quantitative urine Ehrlich reaction $(20,21)$ was carried out on individual or two-hour samples. The number of coproporphyrin determinations and the cases which were studied are given in Table $I$.

As noted in Table $I$, the determinations were often repeated, either with relation to stage of the disease or fluctuation of the jaundice, or in some instances within a brief interval, for purposes of corroboration. The majority of determinations in the infectious hepatitis group were in the period after the disappearance of jaundice.

\section{RESULTS}

The data obtained in the five groups of cases (as noted in Table I), are given in Tables II-VI, respectively. The data in Table II permit some comparison of the UCP in cases of hepatitis, with the results of other tests of liver function, as well as
TABLE I

Composition of clinical material and number of determinations

\begin{tabular}{c|l|c|c|c}
\hline \hline Group & Diagnosis & $\begin{array}{c}\text { Num- } \\
\text { ber of } \\
\text { cases }\end{array}$ & $\begin{array}{c}\text { Number } \\
\text { of deter- } \\
\text { minations } \\
\text { of UCP }\end{array}$ & $\begin{array}{c}\text { Isomer } \\
\text { analy- } \\
\text { ses }\end{array}$ \\
\hline 1 & $\begin{array}{l}\text { Infectious hepatitis* } \\
\text { Infectious mononu- } \\
\text { cleosis }\end{array}$ & $\begin{array}{c}96 \\
\text { Cancer of pancreas or } \\
\text { bile ducts } \\
\text { Common duct stone or } \\
\text { stricture }\end{array}$ & 4172 & 53 \\
Cirrhosis (all types) $\ddagger$ & 48 & 95 & 16 \\
\hline
\end{tabular}

* This group includes cases of epidemic hepatitis and homologous serum jaundice, some of which were studied in Minneapolis, and some at the Schick and DeWitt General Hospitals of the U.S. Army, at Clinton Ia., and Auburn, Cal., respectively; the urine porphyrin studies were carried out in all instances in Minneapolis. The group also includes cases of epidemic and homologous serum jaundice, and of sporadic hepatitis studied in Minneapolis.

$\dagger$ These cases were studied on the Health Service of the University of Minnesota Hospital, Dr. Ruth Boynton, Director. Liver function studies in this group have been reported elsewhere by Dr. Ralph Peterson (26).

$\ddagger$ The cirrhosis data will be considered in detail in the ensuing paper of this series, but are included in the present communication for purposes of comparison, with particular respect to the differential diagnosis of jaundice.

\section{UCP in Relation to Duration of Joundice and Interval after Disappearance of Joundice}

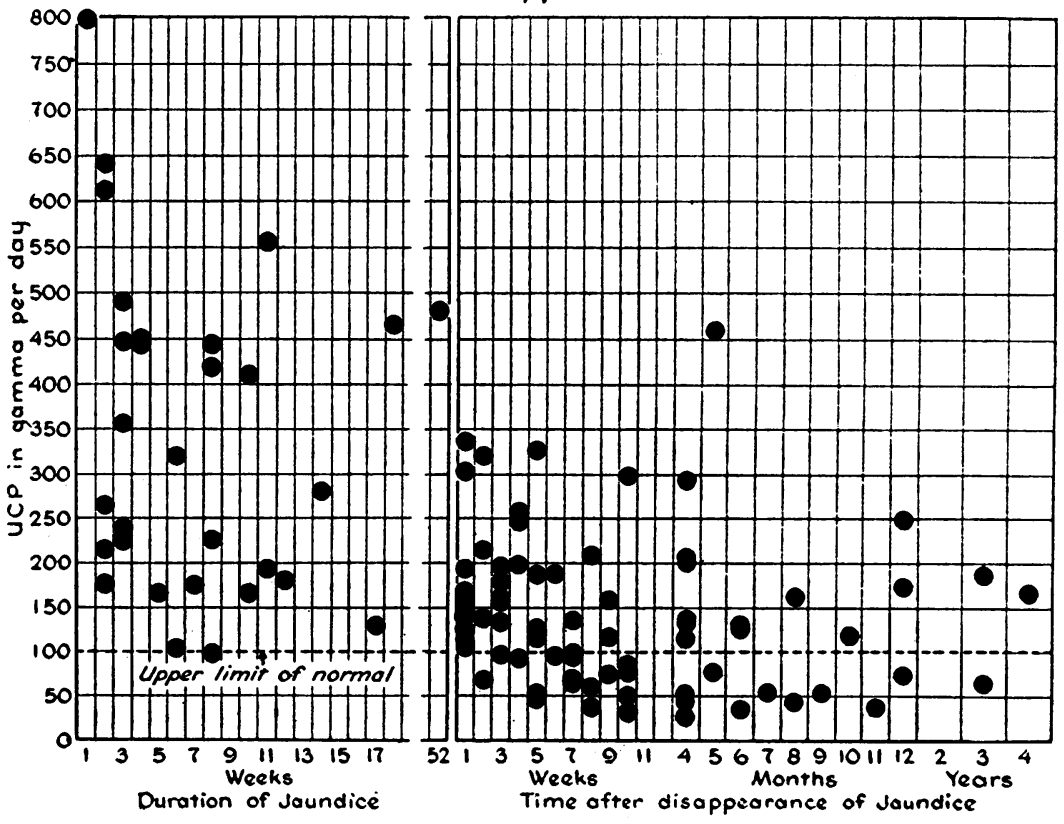

Fic. 1 
TABLE II

UCP in cases of infectious hepatitis, compared with stage of disease, symptoms, and status of the liver

\begin{tabular}{|c|c|c|c|c|c|c|c|c|c|c|c|c|c|c|c|c|c|}
\hline $\begin{array}{c}\text { Case } \\
\text { no. }\end{array}$ & Initials & Sex & Age & Date & $\begin{array}{l}\text { Week of } \\
\text { disease }\end{array}$ & $\begin{array}{c}\text { Week after } \\
\text { disappearance } \\
\text { of jaundice }\end{array}$ & $\begin{array}{l}\text { Symp- } \\
\text { toms* }\end{array}$ & $\begin{array}{l}\text { Liver } \\
\text { enl. }\end{array}$ & $\begin{array}{c}\text { Tender- } \\
\text { ness }\end{array}$ & $\underset{1^{\prime}}{\text { SB }}$ & $\underset{\mathbf{T}}{\mathbf{S B}}$ & Brom & Cc & $\begin{array}{c}\text { CE } \\
\text { per } \\
\text { cent }\end{array}$ & UE & $\begin{array}{l}\text { UU } \\
24 \\
\mathrm{hr} . \\
\end{array}$ & $\begin{array}{l}\text { UCP } \\
\gamma / 24 \\
\text { hrs. }\end{array}$ \\
\hline 1 & T. M. & $\sigma^{7}$ & 30 & $\begin{array}{l}10-10 \\
11-21\end{array}$ & $\begin{array}{l}10 \\
16\end{array}$ & $\begin{array}{l}2 \\
8\end{array}$ & $\begin{array}{l}0 \\
0\end{array}$ & $\begin{array}{r}10 \\
3\end{array}$ & $\stackrel{+}{0}$ & 0.7 & 1.1 & & $\begin{array}{l}3+ \\
2+\end{array}$ & $\begin{array}{l}52 \\
66 \\
\end{array}$ & 0.6 & & $\begin{array}{r}320 \\
60\end{array}$ \\
\hline 2 & J. R. & $\sigma^{\circ}$ & 28 & $\begin{array}{l}10-20 \\
11-21 \\
\end{array}$ & $\begin{array}{r}4 \\
10\end{array}$ & $\begin{array}{l}\text { Never } \mathbf{j} \\
\text { Never } \mathbf{j}\end{array}$ & $\begin{array}{l}\text { I } \\
0\end{array}$ & $\begin{array}{l}0 \\
1\end{array}$ & + & 0.0 & 0.03 & $\begin{array}{l}0 \\
0\end{array}$ & $1+$ & 40 & & & $\begin{array}{r}143 \\
86\end{array}$ \\
\hline 3 & F.F. & $\sigma^{7}$ & 31 & $\begin{array}{l}10-9 \\
11-15\end{array}$ & $\begin{array}{l}34 \\
39\end{array}$ & $\begin{array}{r}5 \\
10\end{array}$ & I & $\begin{array}{l}3 \\
3\end{array}$ & $\stackrel{+}{+}$ & 0.0 & .44 & $\begin{array}{l}3 \\
0\end{array}$ & $\begin{array}{l}0 \\
0\end{array}$ & 54 & .25 & & $\begin{array}{l}47 \\
77\end{array}$ \\
\hline 4 & R. V. & $\sigma^{7}$ & 27 & $\begin{array}{l}10-10 \\
11-20\end{array}$ & $\begin{array}{l}11 \\
17\end{array}$ & $\begin{array}{r}8 \\
14\end{array}$ & I & $\begin{array}{l}1 \\
1\end{array}$ & $\begin{array}{l}0 \\
0\end{array}$ & .03 & 0.1 & 4 & & 80 & & & $\begin{array}{l}209 \\
115\end{array}$ \\
\hline 5 & H. M. & $\sigma^{\circ}$ & 23 & $11-16$ & 22 & 14 & 0 & 4 & 0 & .2 & .65 & 24 & $3+$ & 67 & 3.8 & & 208 \\
\hline 6 & F. R. & $\sigma^{x}$ & 26 & $\begin{array}{l}10-9 \\
11-16\end{array}$ & $\begin{array}{r}6 \\
11\end{array}$ & $\begin{array}{l}\mathbf{j} \\
\mathrm{j}\end{array}$ & $\begin{array}{l}0 \\
0\end{array}$ & $\begin{array}{l}3 \\
3\end{array}$ & $\begin{array}{l}+ \\
+\end{array}$ & $\begin{array}{l}3.7 \\
5.8\end{array}$ & $\begin{array}{l}4.1 \\
9.2\end{array}$ & & $1+$ & 33 & $\begin{array}{l}0.7- \\
3.0\end{array}$ & & $\begin{array}{l}319 \\
193\end{array}$ \\
\hline 7 & M. D. & $\sigma^{7}$ & 23 & $\begin{array}{l}10-1 \\
11-15\end{array}$ & $\begin{array}{l}13 \\
19\end{array}$ & $\begin{array}{r}7 \\
13\end{array}$ & I & $\begin{array}{l}4 \\
5\end{array}$ & $\begin{array}{l}+ \\
0\end{array}$ & 0.0 & 0.17 & 1 & 0 & 57 & 1.8 & & $\begin{array}{r}65 \\
292\end{array}$ \\
\hline 8 & J. T. & $\sigma^{\prime}$ & 35 & $\begin{array}{l}10-7 \\
11-16\end{array}$ & $\begin{array}{r}5 \\
11\end{array}$ & $\begin{array}{l}1 \\
7\end{array}$ & $+t$ & $\begin{array}{l}4 \\
6\end{array}$ & $\stackrel{0}{++}$ & 0.3 & 0.7 & 4 & 0 & 63 & & & $\begin{array}{r}193 \\
99\end{array}$ \\
\hline 9 & H.C. & $\sigma^{\prime}$ & 37 & $\begin{array}{r}9-20 \\
10-27\end{array}$ & $\begin{array}{l}25 \\
30\end{array}$ & $\begin{array}{r}9 \\
14\end{array}$ & ++ & $\begin{array}{l}2 \\
1\end{array}$ & $\begin{array}{l}+ \\
0\end{array}$ & 0.1 & 0.2 & 0 & $\begin{array}{l}0 \\
0\end{array}$ & $\begin{array}{l}45 \\
56\end{array}$ & 2.5 & & $\begin{array}{l}159 \\
133\end{array}$ \\
\hline 10 & R. C. & $\sigma^{\prime \prime}$ & 28 & $\begin{array}{r}9-27 \\
11-21\end{array}$ & $\begin{array}{l}11 \\
18\end{array}$ & $\begin{array}{r}7 \\
14\end{array}$ & I & $\begin{array}{l}3 \\
2\end{array}$ & $\begin{array}{l}0 \\
0\end{array}$ & 0.5 & 1.1 & $\begin{array}{l}9 \\
5\end{array}$ & 0 & & 1.5 & & $\begin{array}{r}138 \\
28\end{array}$ \\
\hline 11 & P.U. & $\sigma^{\circ}$ & 21 & $\begin{array}{l}10-2 \\
11-16\end{array}$ & $\begin{array}{r}4 \\
10\end{array}$ & $j_{5}$ & $\stackrel{+}{0}$ & $\begin{array}{l}2 \\
0\end{array}$ & $\begin{array}{l}0 \\
0\end{array}$ & 2.7 & 4.3 & 0 & $4+$ & & $\begin{array}{l}2.3 \\
0.5\end{array}$ & & $\begin{array}{l}444 \\
115\end{array}$ \\
\hline 12 & J. R. & $\sigma^{\circ}$ & 21 & $\begin{array}{l}10-8 \\
11-15\end{array}$ & $\begin{array}{l}3 \\
8\end{array}$ & $\mathbf{s i} \mathbf{j}$ & ${ }_{I}^{+}$. & $\begin{array}{l}4 \\
1\end{array}$ & + & 3.1 & 5.5 & 0 & $1+$ & 36 & 3.8 & & $\begin{array}{r}448 \\
99\end{array}$ \\
\hline 13 & A. M. & $\sigma^{\circ}$ & 21 & $10-1$ & 24 & 4 & 0 & 0 & 0 & 0.1 & 0.2 & 8 & 0 & 47 & $\begin{array}{l}1.8- \\
4.6\end{array}$ & & 92 \\
\hline 14 & C. M. & $\sigma^{\circ}$ & 37 & $\begin{array}{r}9-20 \\
11-15 \\
\end{array}$ & $\begin{array}{l}36 \\
39\end{array}$ & $\begin{array}{l}30 \\
33\end{array}$ & $\begin{array}{c}++ \\
I\end{array}$ & $\begin{array}{l}5 \\
0\end{array}$ & $\begin{array}{c}++ \\
0\end{array}$ & 0.3 & 0.6 & & 0 & 69 & $\begin{array}{l}2.0- \\
2.7\end{array}$ & & $\begin{array}{r}161 \\
52\end{array}$ \\
\hline 15 & W. W. & $\sigma^{7}$ & 40 & $9-24$ & 56 & 46 & I & 1 & 0 & 0.0 & 0.3 & 0 & 0 & 61 & 0.7 & & 172 \\
\hline 16 & F. H. & $\sigma^{\circ}$ & 40 & $\begin{array}{r}9-20 \\
11-15\end{array}$ & $\begin{array}{l}3 \text { yr. } \\
10 \text { wk. } \\
3 \text { yr. } \\
14 \text { wk. }\end{array}$ & $\begin{array}{c}\text { Approx. } \\
3 \mathrm{yr} . \\
\text { Approx. } \\
3 \mathrm{yr} .\end{array}$ & $\begin{array}{l}+ \\
+\end{array}$ & $\begin{array}{l}0 \\
0\end{array}$ & $\begin{array}{l}0 \\
0\end{array}$ & 0.2 & 0.44 & 0 & 0 & 49 & $\begin{array}{l}1.1- \\
3.3\end{array}$ & & $\begin{array}{r}187 \\
63\end{array}$ \\
\hline 17 & M. H. & $\sigma^{\prime}$ & 21 & $9-28$ & 4 & 2 & 0 & 4 & 0 & 0.5 & 0.65 & 15 & 0 & & 0.5 & & 213 \\
\hline 18 & J. H. & $\sigma^{\pi}$ & 23 & $9-20$ & 1 yr. & 6 & + & 3 & + & 0.0 & 0.2 & 0 & & 60 & 2.0 & & 189 \\
\hline 19 & W. M. & $\sigma^{\circ}$ & 22 & $9-28$ & 10 & 3 & 0 & 2 & 0 & 0.2 & 0.58 & 5 & 0 & & 1.0 & & 96 \\
\hline 20 & J.D. & $\sigma^{7}$ & 32 & $10-2$ & 19 & 17 & 0 & 0 & 0 & .23 & .44 & & 0 & & 2.3 & & 76 \\
\hline
\end{tabular}

* Symptoms: I = Indefinite or questionable;,+++ mild or moderate weakness, fatigue, anorexia; +++ severe anorexia and weakness, patient very sick but not comatose.

$\dagger$ Enl.: Cm. below costal margin in midclavicular line. Tenderness: $+=$ slight, $++=$ moderate, $+++=$ marked.

Key: SB = Serum bilirubin $1^{\prime}=$ prompt direct

$T=$ total

$\mathrm{CE}=$ Cholesterol ester \%
Brom $=\%$ retention of Bromsulfalein in blood 45' after $5 \mathrm{mg}$. per kilo body weight

$\mathrm{UE}=$ Urine Ehrlich units per 2-4 P.M. urine sample
$\mathrm{CC}=$ Cephalin cholesterol flocculation at 24 hours

$\mathrm{UU}=\mathrm{mg}$. urobilinogen in $24 \mathrm{hr}$. urine 
TABLE II-Continued

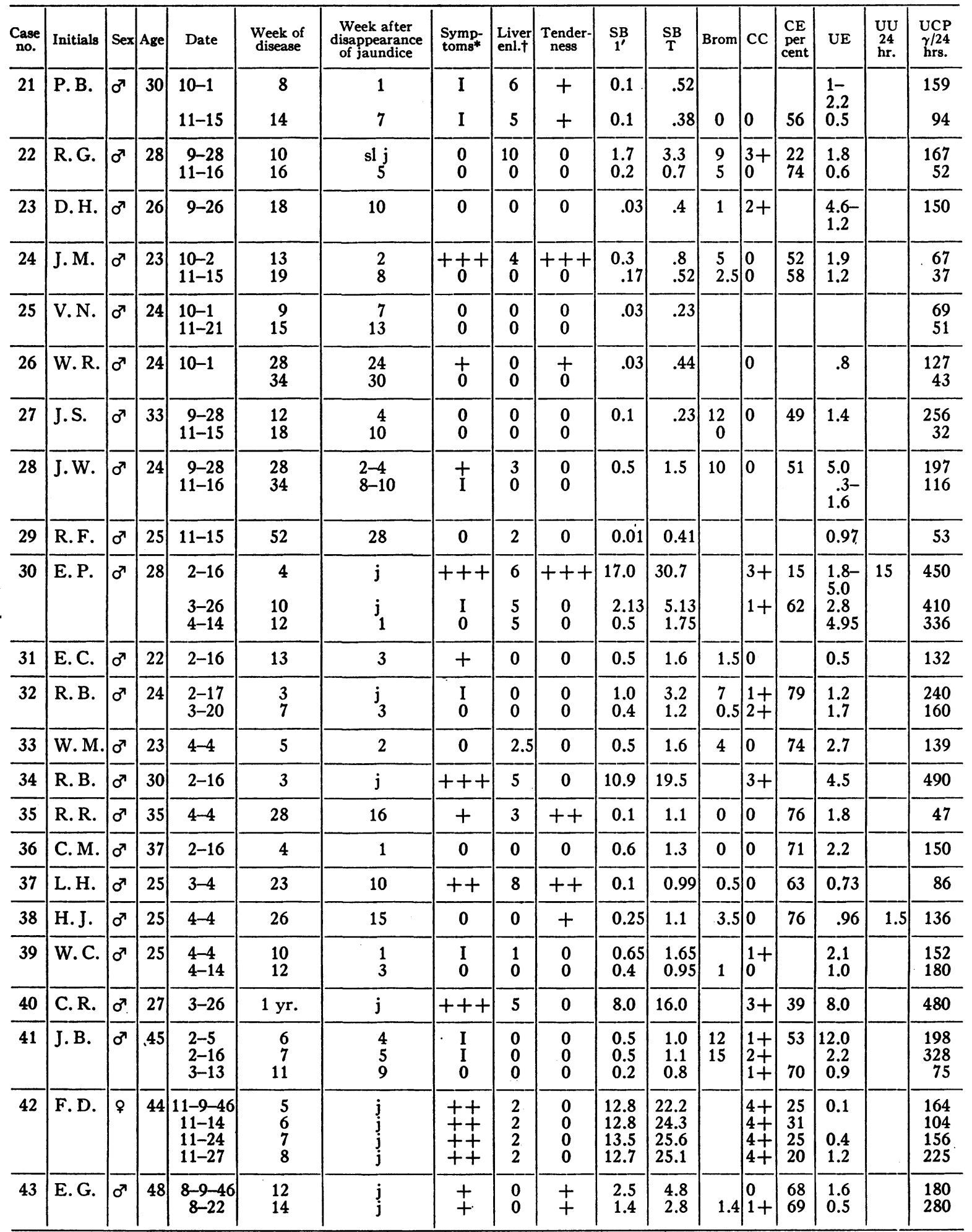


TABLE II-Continued

\begin{tabular}{|c|c|c|c|c|c|c|c|c|c|c|c|c|c|c|c|c|c|}
\hline $\begin{array}{c}\text { Case } \\
\text { no. }\end{array}$ & Initials & Sex & Age & Date & $\begin{array}{l}\text { Week of } \\
\text { disease }\end{array}$ & $\begin{array}{l}\text { Week after } \\
\text { disappearance } \\
\text { of jaundice }\end{array}$ & $\begin{array}{l}\text { Symp- } \\
\text { toms* }\end{array}$ & $\left|\begin{array}{l}\text { Liver } \\
\text { enl. }\end{array}\right|$ & $\begin{array}{c}\text { Tender- } \\
\text { ness }\end{array}$ & $\underset{\mathbf{1}^{\prime}}{\text { SB }}$ & $\underset{\mathbf{T}}{\mathbf{S B}}$ & Brom & cc & $\begin{array}{l}\text { CE } \\
\text { per } \\
\text { cent }\end{array}$ & UE & $\begin{array}{l}\text { UU } \\
24 \\
\text { hr. }\end{array}$ & $\begin{array}{l}\text { UCP } \\
\gamma / 24 \\
\text { hrs. }\end{array}$ \\
\hline 44 & B. K. & $0^{7}$ & 32 & $\mid \begin{array}{c}5-15-46 \\
6-1 \\
6-2 \\
7-10\end{array}$ & $\begin{array}{l}18 \\
20 \\
20 \\
25\end{array}$ & $\begin{array}{l}\mathrm{j} \\
\mathbf{1} \\
1 \\
6\end{array}$ & $\begin{array}{l}+ \\
+ \\
+\end{array}$ & $\begin{array}{l}5 \\
3 \\
3 \\
3\end{array}$ & $\begin{array}{l}+ \\
+ \\
+ \\
0\end{array}$ & $\begin{array}{l}1.9 \\
0.9 \\
0.2\end{array}$ & $\begin{array}{l}4.5 \\
1.8 \\
0.5\end{array}$ & & $\left|\begin{array}{l}3+ \\
1+\end{array}\right|$ & $\begin{array}{l}76 \\
67\end{array}$ & $\begin{array}{l}0.9 \\
0.6\end{array}$ & & $\begin{array}{r}465 \\
134 \\
164 \\
94\end{array}$ \\
\hline 45 & A. $G$. & $0^{7}$ & 21 & $\mid \begin{array}{c}3-12-46 \\
3-17 \\
5-2 \\
10-16\end{array}$ & $\begin{array}{l}19 \\
20 \\
26 \\
48\end{array}$ & $\begin{array}{l}16 \\
17 \\
23 \\
45\end{array}$ & + & $\begin{array}{l}2 \\
2 \\
0 \\
0\end{array}$ & $\begin{array}{l}+ \\
+ \\
+ \\
0\end{array}$ & $\begin{array}{c}0.2 \\
.06 \\
0.1\end{array}$ & $\begin{array}{l}1.0 \\
\\
0.8 \\
0.7\end{array}$ & 3 & $\begin{array}{l}0 \\
0 \\
0\end{array}$ & $\begin{array}{l}73 \\
74\end{array}$ & $\begin{array}{l}0.7 \\
0.5\end{array}$ & $\begin{array}{r}10.4 \\
1.0\end{array}$ & $\begin{array}{l}203 \\
460 \\
129 \\
249\end{array}$ \\
\hline 46 & A. G. & $\sigma^{7}$ & 40 & $\begin{array}{l}4-16 \\
4-24\end{array}$ & $\begin{array}{l}1 \\
3\end{array}$ & $\stackrel{\mathbf{j}}{\text { sl j }}$ & + & $\begin{array}{l}2 \\
0\end{array}$ & $\begin{array}{l}0 \\
0\end{array}$ & $\begin{array}{l}4.1 \\
0.9\end{array}$ & $\begin{array}{l}7.1 \\
1.7\end{array}$ & 9.5 & $\begin{array}{l}4+ \\
4+\end{array}$ & 75 & & 22.3 & $\begin{array}{l}779 \\
356\end{array}$ \\
\hline 47 & A. C. & $\%$ & 28 & $4-13$ & 3 yr. & 1 yr. 2 mo. & + & 1 & $+t$ & 0.1 & 0.7 & $3 \%$ & 0 & 75 & 1.7 & & 72 \\
\hline 48 & C. M. & $\sigma^{7}$ & 30 & $5-26$ & 8 & $\mathrm{j}$ & I & 1 & + & 26 & 37.9 & & 0 & & 4.6 & & 420 \\
\hline 49 & V.A. & $\sigma^{7}$ & 41 & $\begin{array}{l}2-24 \\
3-15 \\
4-8 \\
5-6 \\
6-17 \\
8-8\end{array}$ & $\begin{array}{r}8 \\
11 \\
14 \\
18 \\
23 \\
30\end{array}$ & $\begin{array}{r}\mathrm{j} \\
\mathrm{j} \\
1 \\
5 \\
10 \\
17\end{array}$ & $\begin{array}{l}+ \\
+ \\
0 \\
0 \\
0 \\
0\end{array}$ & $\begin{array}{l}2 \\
2 \\
0 \\
0 \\
0 \\
0\end{array}$ & $\begin{array}{l}+ \\
0 \\
0 \\
0 \\
0 \\
0\end{array}$ & $\begin{array}{l}5.9 \\
2.6 \\
0.6 \\
0.3 \\
0.2 \\
0.2\end{array}$ & \begin{tabular}{|r}
10.1 \\
4.6 \\
1.5 \\
0.8 \\
0.6 \\
0.6
\end{tabular} & $3 \%$ & $\mid \begin{array}{l}0 \\
2+ \\
0 \\
0 \\
0\end{array}$ & $\begin{array}{l}55 \\
69\end{array}$ & & $\begin{array}{c}11.1 \\
26 \\
2.7 \\
2.9 \\
0.7 \\
1.2\end{array}$ & $\begin{array}{l}445 \\
554 \\
302 \\
188 \\
259 \\
253\end{array}$ \\
\hline 50 & M. B. & 9 & 30 & $12-1$ & $1 \mathrm{yr}$. & $\begin{array}{l}\text { About } \\
\qquad 11 \mathrm{mo} .\end{array}$ & I & 0 & 0 & 0.2 & 2.1 & $2 \%$ & $1+$ & 74 & 0.6 & 1.0 & 36 \\
\hline 51 & L. H. & 9 & 32 & $\begin{array}{l}9-4 \\
9-7 \\
9-24\end{array}$ & $\begin{array}{l}2 \\
2 \\
3\end{array}$ & $\begin{array}{l}\mathrm{j} \\
\mathrm{j} \\
1\end{array}$ & $\stackrel{+}{+}$ & $\begin{array}{l}1 \\
1 \\
0\end{array}$ & $\stackrel{+}{+}$ & $\begin{array}{r}1.8 \\
.16\end{array}$ & $\begin{array}{l}3.0 \\
0.7\end{array}$ & $\begin{array}{c}30.5 \\
3\end{array}$ & $\left|\begin{array}{l}4+ \\
4+\end{array}\right|$ & 35 & & 20.0 & $\begin{array}{l}265 \\
642 \\
148\end{array}$ \\
\hline 52 & M. H. & 9 & 27 & $2-28$ & 16 & 1 & + & 1 & + & 0.8 & 1.7 & 12.5 & $3+\mid$ & 60 & & 2.6 & 116 \\
\hline 53 & I.S. & 9 & 52 & $12-4$ & 17 & $\mathbf{j}$ & + & 0 & 0 & 1.2 & 2.2 & & $2+$ & 67 & & 0.7 & 130 \\
\hline 54 & G. B. & $\sigma^{7}$ & 30 & $\begin{array}{l}5-20 \\
7-8\end{array}$ & $\begin{array}{l}31 \\
37\end{array}$ & $\begin{array}{l}13 \\
19\end{array}$ & $\stackrel{+}{0}$ & $\dot{t}$ & $\begin{array}{l}0 \\
0\end{array}$ & $\begin{array}{l}0.2 \\
0.2\end{array}$ & $\begin{array}{l}2.0 \\
1.8\end{array}$ & $\begin{array}{l}2.4 \\
2.0\end{array}$ & $\begin{array}{l}0 \\
0\end{array}$ & & & $\begin{array}{l}4.2 \\
0.3\end{array}$ & $\begin{array}{l}143 \\
135\end{array}$ \\
\hline 55 & A. B. & $\sigma^{7}$ & 40 & $|4-30-46|$ & 28 & 22 & + & & 0 & 0.2 & 2.8 & 5.0 & $1+$ & & 1.9 & & 35 \\
\hline 56 & P.T. & $\sigma^{7}$ & 54 & $\left|\begin{array}{r}4-28-46 \\
6-7-46\end{array}\right|$ & $\begin{array}{l}2 \\
7\end{array}$ & $\mathrm{j}_{1}$ & $\stackrel{+}{+}$ & $\stackrel{+}{0}$ & $\stackrel{+}{0}$ & $\begin{array}{r}15.4 \\
0.6\end{array}$ & $\begin{array}{r}26.7 \\
1.2\end{array}$ & & $\begin{array}{l}3+ \\
0\end{array}$ & $\begin{array}{l}26 \\
67\end{array}$ & $\begin{array}{r}10.0 \\
3.2\end{array}$ & & $\begin{array}{l}611 \\
105\end{array}$ \\
\hline 57 & G. T. & $\sigma^{7}$ & 50 & $\left|\begin{array}{r}4-19-48 \\
5-8-48\end{array}\right|$ & $\begin{array}{l}2 \\
4\end{array}$ & $\mathrm{j}_{4}$ & + & $\begin{array}{l}2 \\
2\end{array}$ & + & $\begin{array}{r}4.6 \\
14.7\end{array}$ & $\begin{array}{r}7.7 \\
31.7\end{array}$ & & $\begin{array}{l}4+ \\
4+\end{array}$ & $\begin{array}{l}50.5 \\
21\end{array}$ & 11.2 & 1.0 & $\begin{array}{l}224 \\
245\end{array}$ \\
\hline 58 & M.S. & 9 & 19 & $|7-17-47|$ & 2 & Never $\mathbf{j}$ & + & + & + & 0.2 & 0.5 & 2 & $1+$ & & & 1.5 & 45 \\
\hline 59 & H.F. & 9 & 37 & $7-2-47$ & $4 \mathrm{yr}$. & $4 \mathrm{yr}$. & + & 0 & 0 & 0.2 & 1.1 & 3 & 0 & & 4.5 & & 153 \\
\hline 60 & L. S. & $\%$ & 47 & $5-2-45$ & 2 & $\mathbf{j}$ & + & 1 & + & 9.0 & 13.0 & & $3+$ & 17 & & & 178 \\
\hline 61 & R. G. & $0^{7}$ & 21 & $7-1-45$ & 12 & 10 & + & 1 & + & 0.1 & 0.5 & & 0 & & & 0.3 & 119 \\
\hline 62 & H. H. & $\sigma^{x}$ & 50 & $\left|\begin{array}{l}3-18-48 \\
3-29-48 \\
4-11-48 \\
4-25-48\end{array}\right|$ & $\begin{array}{l}3 \\
5 \\
7 \\
9\end{array}$ & $\begin{array}{l}\mathrm{j} \\
1 \\
3 \\
5\end{array}$ & $\begin{array}{l}+ \\
+ \\
+ \\
0\end{array}$ & $\begin{array}{l}2 \\
1 \\
1 \\
0\end{array}$ & $\begin{array}{l}+ \\
+ \\
+ \\
0\end{array}$ & $\begin{array}{l}1.3 \\
0.4\end{array}$ & $\begin{array}{l}2.5 \\
1.1\end{array}$ & & $\begin{array}{l}3+ \\
0 \\
0 \\
0\end{array}$ & 67 & & $\begin{array}{l}1.3 \\
1.0 \\
1.0\end{array}$ & $\begin{array}{l}222 \\
141 \\
158 \\
125\end{array}$ \\
\hline
\end{tabular}

with the patients' symptoms, approximate liver size, and degree of tenderness, at various stages of the disease. Table IIA includes supplementary data on the UCP; in these instances additional information as to hepatic function was lacking or fragmentary.
In Figure 1, the values for UCP in the cases of hepatitis are plotted with relation to the duration of jaundice or the interval from the disappearance of jaundice. This figure includes all of the determinations in all cases in which there had been jaundice. As a matter of fact, the present mate- 
TABLE IIA

Additional UCP determinations in cases of infectious hepatitis

\begin{tabular}{|c|c|c|c|c|c|}
\hline Case no. & Initials & Age & Sex & $\begin{array}{c}\text { Presence } \\
\text { or absence } \\
\text { of jaundice }\end{array}$ & $\begin{array}{c}\text { UCP in } \\
\gamma / 24 \mathrm{hrs} .\end{array}$ \\
\hline $\begin{array}{l}63 \\
64 \\
65\end{array}$ & $\begin{array}{l}\text { J. B. } \\
\text { A. P. } \\
\text { E. S. }\end{array}$ & $\begin{array}{l}67 \\
29 \\
30\end{array}$ & $\begin{array}{l}9 \\
\$ \\
\sigma^{4}\end{array}$ & \pm & $\begin{array}{r}257 \\
206 \\
\left\{\begin{array}{l}739 \\
448 \\
425 \\
472 \\
220 \\
155\end{array}\right. \\
\left\{\begin{array}{r}134 \\
91 \\
158\end{array}\right.\end{array}$ \\
\hline $\begin{array}{l}66 \\
67\end{array}$ & $\begin{array}{l}\text { C. R. } \\
\text { E. R. }\end{array}$ & $\begin{array}{l}31 \\
24\end{array}$ & $\begin{array}{l}\sigma^{x} \\
\sigma^{7}\end{array}$ & - & $\left\{\begin{array}{r}197 \\
39 \\
42 \\
77 \\
120 \\
37\end{array}\right.$ \\
\hline $\begin{array}{l}68 \\
69 \\
70 \\
71 \\
72 \\
73 \\
74\end{array}$ & $\begin{array}{l}\text { J. M. } \\
\text { L. S. } \\
\text { I. N. } \\
\text { C. L. F. } \\
\text { O. D. } \\
\text { L. F. } \\
\text { S. S. }\end{array}$ & $\begin{array}{l}59 \\
42 \\
24 \\
23 \\
54 \\
45 \\
55\end{array}$ & $\begin{array}{l}0^{7} \\
0^{7} \\
0^{7} \\
0^{7} \\
0^{7} \\
0^{\prime \prime} \\
9\end{array}$ & $\begin{array}{l}+ \\
+ \\
+ \\
+ \\
+ \\
+ \\
+\end{array}$ & $\begin{array}{l}432 \\
451 \\
252 \\
346 \\
205 \\
242 \\
265 \\
235\end{array}$ \\
\hline $\begin{array}{l}75 \\
76 \\
77 \\
78 \\
79 \\
80 \\
81 \\
82 \\
83 \\
84 \\
85 \\
86 \\
87 \\
88 \\
89 \\
90 \\
91 \\
92 \\
93 \\
94 \\
95 \\
96\end{array}$ & $\begin{array}{l}\text { M.A. } \\
\text { J.M. } \\
\text { W.S. } \\
\text { N.T. } \\
\text { J.O. } \\
\text { H. W. } \\
\text { D. W. } \\
\text { R. S. } \\
\text { R. K. } \\
\text { B. R. } \\
\text { P. T. } \\
\text { C. S. } \\
\text { J.G. } \\
\text { F. W. } \\
\text { M.G. } \\
\text { R. F. } \\
\text { B. R. K. } \\
\text { H. F. } \\
\text { G. G. } \\
\text { T. C. } \\
\text { C. B. } \\
\text { E. E. }\end{array}$ & $\begin{array}{r}25 \\
21 \\
23 \\
21 \\
34 \\
42 \\
27 \\
23 \\
24 \\
30 \\
21 \\
26 \\
27 \\
4 \\
25 \\
25 \\
22 \\
53 \\
23 \\
40 \\
74 \\
20\end{array}$ & 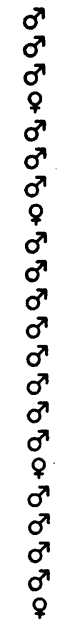 & $\begin{array}{l}\bar{t} \\
+ \\
+ \\
+ \\
+ \\
\bar{t} \\
+ \\
+ \\
+ \\
\bar{t} \\
\pm \\
\bar{t} \\
\bar{t} \\
\bar{t} \\
+ \\
+\end{array}$ & $\begin{array}{l}151 \\
170 \\
312 \\
197 \\
222 \\
505 \\
150 \\
241 \\
314 \\
296 \\
210 \\
160 \\
208 \\
179 \\
141 \\
540 \\
177 \\
145 \\
210 \\
304 \\
279 \\
182\end{array}$ \\
\hline
\end{tabular}

rial includes but one instance of what was believed to represent hepatitis without jaundice (Case 2 in Table II). The upper limit of normal of $100 \gamma$, as indicated in Figure 1, was established with relation to the value of the mean plus two standard deviations, or $97, \gamma$. One instance of the 53 in the normal group was above this value, with $99 \gamma$ (see paper I of this series [14]).

As shown in Figure 1 and Table II, a number of the cases of hepatitis were first seen in a late stage of the disease, weeks or months after the
TABLE III

Copropor phyrin isomer distribution in 24-hour urine samples from cases of hepatitis

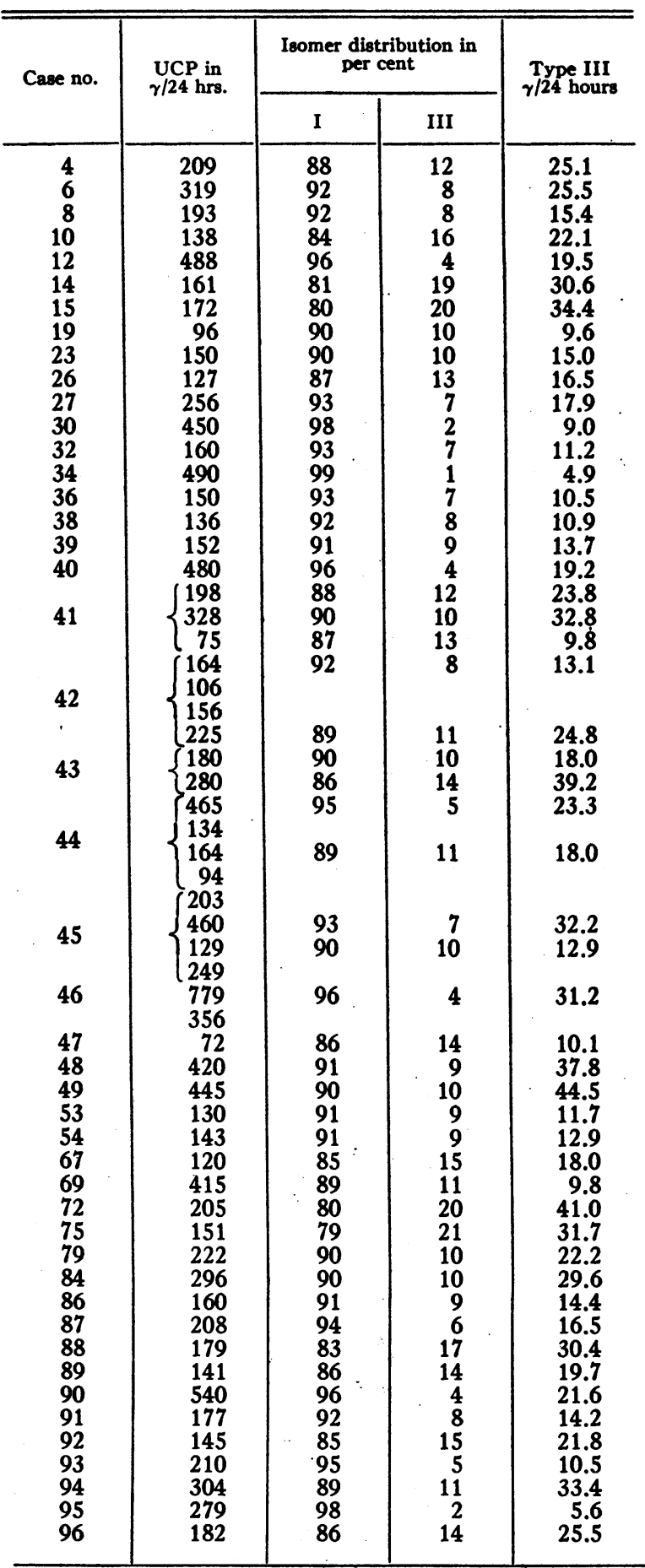

disappearance of jaundice. At least two of these are sufficiently instructive to be given in more detail in the following: 
TABLE IV

$U C P$ and isomer distribution in cases of infectious mononucleosis

\begin{tabular}{|c|c|c|c|c|}
\hline \multirow{2}{*}{ Case } & \multirow{2}{*}{$\begin{array}{l}\text { UCP in } \\
\gamma / 24 \mathrm{hrs} .\end{array}$} & \multicolumn{2}{|c|}{$\begin{array}{l}\text { Isomer distribution } \\
\text { in per cent }\end{array}$} & \multirow{2}{*}{$\begin{array}{l}\text { Type III in } \\
\gamma / 24 \mathrm{hrs} .\end{array}$} \\
\hline & & I & III & \\
\hline $\begin{array}{l}\text { 1. D. J. } \\
\text { 2. B. R. } \\
\text { 3. M. G. } \\
\text { 4. L. V. B. } \\
\text { 5. G. B. } \\
\text { 6. H. S. } \\
\text { 7. E. S. } \\
\text { 8. P. C. } \\
\text { 9. C. M. } \\
\text { 10. E. B. } \\
\text { 11. E. F. } \\
\text { 12. E. W. } \\
\text { 13. D. S. } \\
\text { 14. F. K. } \\
\text { 15. T. G. } \\
\text { 16. D. E. } \\
\text { 17. F. S. } \\
\text { 18. S. A. } \\
\text { 19. R. G. } \\
\text { 20. D. D. } \\
\text { 21. C. A. } \\
\text { 22. A. H. } \\
\text { 23. K. M. } \\
\text { 24. C. D. } \\
\text { 25. G. L. }\end{array}$ & $\begin{array}{r}189 \\
163 \\
410 \\
147 \\
364 \\
111 \\
425 \\
123 \\
282 \\
133 \\
249 \\
113 \\
219 \\
113 \\
143 \\
152 \\
46 \\
133 \\
71 \\
45 \\
177 \\
42 \\
73 \\
77 \\
122\end{array}$ & $\begin{array}{l}88 \\
81 \\
96 \\
80 \\
89 \\
82 \\
92 \\
82 \\
93 \\
80 \\
95 \\
90 \\
85 \\
90 \\
88 \\
92\end{array}$ & $\begin{array}{r}12 \\
19 \\
4 \\
20 \\
11 \\
18 \\
8 \\
18 \\
7 \\
20 \\
5 \\
10 \\
15 \\
10 \\
12 \\
8\end{array}$ & $\begin{array}{l}23 \\
31 \\
16 \\
29 \\
40 \\
20 \\
34 \\
22 \\
20 \\
27 \\
12 \\
11 \\
33 \\
11 \\
17 \\
12\end{array}$ \\
\hline
\end{tabular}

1. Case 45, A. G., male 21, farmer. The patient was first seen at the University Hospital on March 11, 1946. He stated that about six months earlier he developed nausea and anorexia, shortly followed by jaundice which persisted for two months. During the last four months he felt fairly well and had resumed his work, but was bothered by persistent discomfort and tenderness in the right upper abdomen. Examination revealed an enlarged tender liver and a palpable spleen. Routine laboratory studies were normal. As seen in Table II, the fractional serum bilirubin, thymol turbidity, cephalin cholesterol flocculation, bromsulfalein, cholesterol and ester percentage, were all within normal limits. The serum proteins, hippuric acid synthesis, and prothrombin time were also normal. The urine Ehrlich test on individual samples was normal, but the 24-hour urine urobilinogen was $10.4 \mathrm{mg}$., in other words, considerably elevated. The UCP was markedly increased, usually above $200 \gamma / 24$ hours (see Table II). The liver biopsy revealed evidence of an active hepatitis, i.e., small foci of cellular exudate with occasional necrosis, but no fibrosis.

2. Case 49, V. A., male, 41, illustrator. This case is presented in more detail because of the unusually favorable opportunity for study that was presented during the latter weeks of a prolonged "catarrhal" jaundice or sporadic infectious hepatitis. Following is a brief summary of the salient clinical features:

The first day of observation, Figure 2, was February 24,1947 . At this time the patient had been jaundiced for two months. On December 7, 1946, he experienced an acute attack of diarrhea, nausea and vomiting, of 12 hours' duration. He recovered and felt quite well, but on December 26, he noted fever, malaise, and pain in the muscles. His urine became dark, and he consulted a physician who made a diagnosis of infectious jaundice. When first seen at the University Hospital the liver was moderately enlarged and tender. Within three weeks the tenderness had disappeared and the jaundice had markedly diminished. The liver was still palpable. By April 8, the jaundice had disappeared though the serum bilirubin was still distinctly elevated. Although the patient's appetite had returned, a moderate lassitude persisted throughout the summer. He did not have energy enough to play golf which he ordinarily enjoyed. By November of 1947, however, he believed that he had regained an entirely normal status. As noted in Figure 2, the results of the liver function studies, except the UCP, were normal by the 65th day of observation (corresponding to April 30, 1947). The UCP, however, remained considerably elevated, the value on the 171st day (August 14, 1947), being 253. Later determinations have continued to show abnormally high values, as seen in Table VII. The patient feels quite well (December 15, 1948) but has now developed a number of small spider nevi over the neck, upper chest, and hands. The liver is palpable at the costal margin, not tender.

The total coproporphyrin values together with the percentage and actual amount of each isomer as determined in 46 cases of infectious hepatitis, are given in Table III. Similar data for the infectious mononucleosis group are shown in Table IV. In Figure 3, the initial values obtained for the total UCP and per cent of type III isomer, in the first 40 cases of hepatitis to be studied in this way, are plotted in comparison with the values for the normal (Minneapolis) series previously reported (14), and for 38 cases of acute poliomyelitis. 
UCP and Other Liver Function Studies in Subsiding Infectious Hepatitis

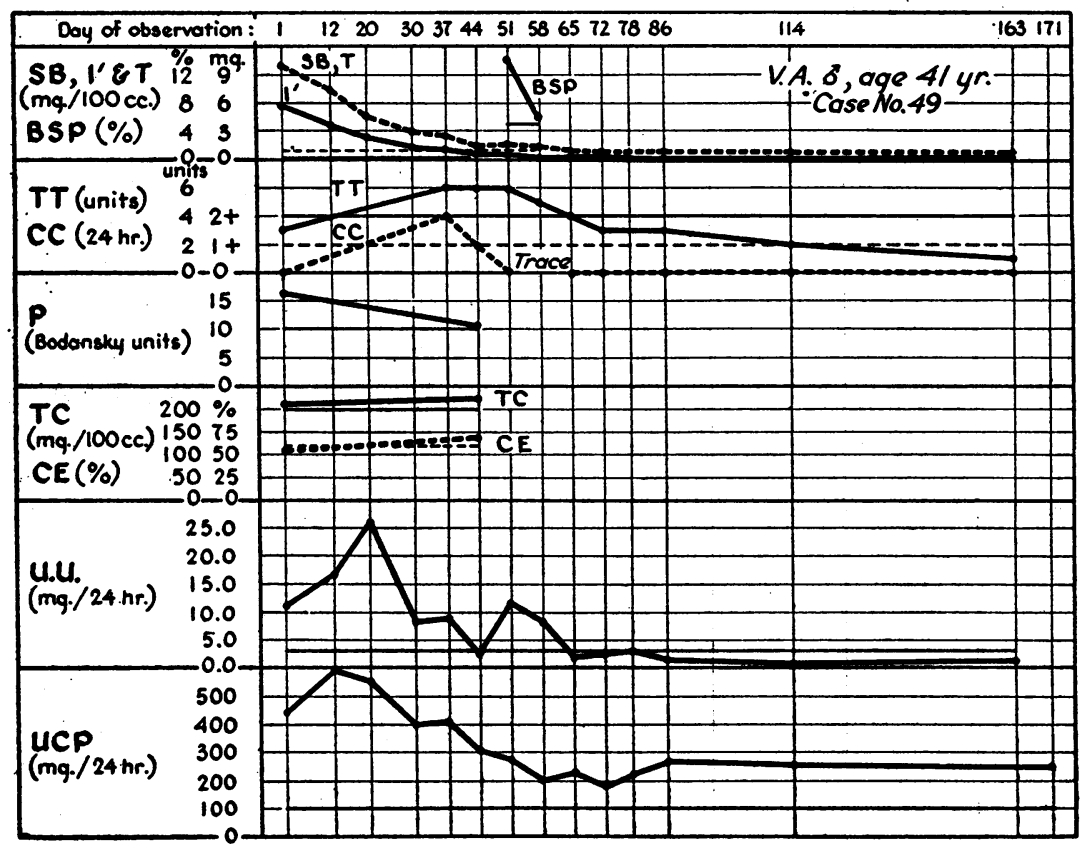

Fic. 2

UCP and Percentage of Type III Isomer in Poliomyelitis and Infectious Hepatitis

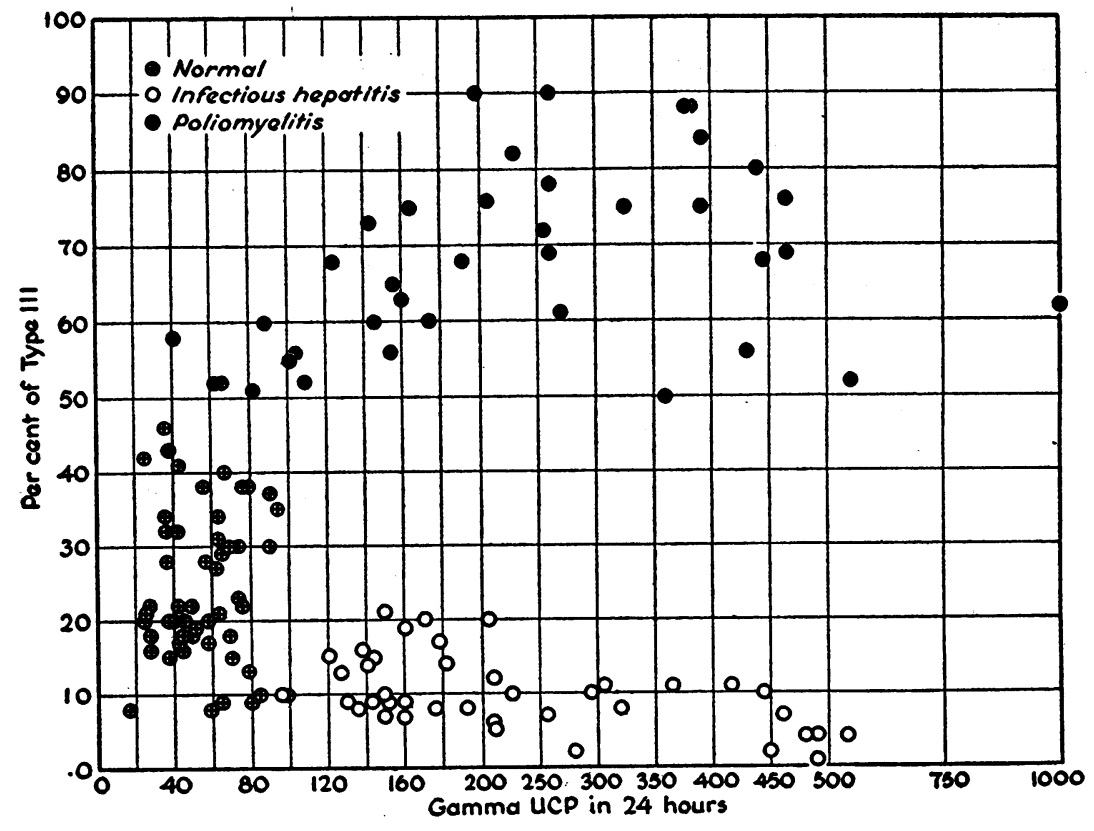

FIg. 3 
The latter data have also been reported previously (22) and are included here only for purposes of comparison with the results in the hepatitis cases. One instance was of particular interest because of the likelihood of coexistence of infectious hepatitis and poliomyelitis.

Case 51, L. H. female, 32, housewife. This patient was seen during the epidemic of poliomyelitis in 1946. She complained of headache and stiff neck, and there was fever. The spinal fluid was found to contain 17 mononuclear cells per cu. mm. When first seen, there was distinct jaundice, in ad- dition to the findings indicative of poliomyelitis. A history was obtained of painless jaundice suffered by her son and several individuals in the neighborhood about six weeks earlier. The patient had observed dark urine at the outset of her own illness. The liver was not palpable or tender at any time. The laboratory data as seen in Table II revealed marked liver functional impairment. The first UCP on September 4, was $265 \gamma / 24$ hours; three days later it was $642 \gamma$, and at this time 82 per cent was type I, the remainder type III. This represents $116 \gamma$ of type III. In paper I of this

TABLE V

$U C P$ in cases of cancer of the pancreas, bile ducts, or liver

\begin{tabular}{|c|c|c|c|c|c|c|c|c|c|c|c|c|}
\hline \multirow{2}{*}{$\begin{array}{l}\text { Case } \\
\text { no. }\end{array}$} & \multirow{2}{*}{ Initials } & \multirow{2}{*}{ Sex } & \multirow{2}{*}{ Age } & \multirow{2}{*}{ Diagnosis } & \multirow{2}{*}{$\begin{array}{c}\text { Diag- } \\
\text { nosis } \\
\text { by* }\end{array}$} & \multirow{2}{*}{$\begin{array}{c}\text { Date of } \\
\text { determi- } \\
\text { nation }\end{array}$} & \multicolumn{2}{|c|}{ SBt } & \multirow{2}{*}{$\begin{array}{c}\text { UCP } \\
\gamma / 24 \mathrm{hrs} .\end{array}$} & \multirow{2}{*}{$\begin{array}{c}\text { Per cent } \\
\text { I }\end{array}$} & \multirow{2}{*}{$\begin{array}{l}\text { Per cent } \\
\text { III }\end{array}$} & \multirow{2}{*}{$\begin{array}{c}\gamma \text { III/ } \\
24 \text { hrs. }\end{array}$} \\
\hline & & & & & & & $1^{\prime}$ & $\mathbf{T}$ & & & & \\
\hline 1 & C. $\mathbf{K}$. & ? & 56 & Ca. bile ducts & A & $\begin{array}{l}8 / 27 / 44 \\
8 / 29 / 44 \\
8 / 30 / 44\end{array}$ & 22.0 & 25.5 & $\begin{array}{l}330 \\
269 \\
380\end{array}$ & 95 & 5 & 17 \\
\hline 2 & J. W. & $0^{x}$ & 51 & Adeno ca. of bile ducts & 0 & $3 / 2 / 46$ & 12.8 & 23.0 & 314 & 89 & 11 & 35 \\
\hline 3 & H. A. & $\sigma^{x}$ & 74 & Ca. C.B.D. & O & $12 / 6 / 46$ & 16.5 & 23.2 & 257 & & & \\
\hline 4 & H. A. & $\sigma^{x}$ & 59 & Ca. C.B.D. & $\mathbf{O}$ & $7 / 18 / 46$ & 24.0 & 41.6 & 226 & 81 & 19 & 43 \\
\hline 5 & G. H. & 9 & 50 & Ca. C.B.D. & O & $\begin{array}{l}5 / 27 / 46 \\
5 / 29 / 46\end{array}$ & 15.1 & 31.2 & $\begin{array}{l}381 \\
172\end{array}$ & 94 & 6 & 23 \\
\hline 6 & O. 0 . & $\sigma^{7}$ & 53 & Ca. head of pancreas & $\mathbf{O}$ & $4 / 26 / 46$ & 3.9 & 6.5 & 365 & 86 & 14 & 51 \\
\hline 7 & E. P. & - & 77 & Ca. body of pancreas & $\mathbf{O}$ & $\begin{array}{l}12 / 10 / 45 \\
12 / 11 / 45 \\
12 / 22 / 45\end{array}$ & 6.6 & 9.6 & $\begin{array}{l}201 \\
180 \\
144\end{array}$ & 78 & 22 & 51 \\
\hline 8 & G. S. & ه & 76 & Adeno ca. of bile ducts & $\mathrm{O}$ & $12 / 25 / 46$ & 13.8 & 24.0 & 174 & & & \\
\hline 9 & W. G. & $\sigma^{7}$ & 70 & Ca. pancreas & A & $4 / 17 / 47$ & & & 196 & 82 & 18 & 36 \\
\hline 10 & J. D. & & & Ca. pancreas & A & $5 / 6 / 47$ & & & 206 & 80 & 20 & \\
\hline 11 & J. W. & $\sigma^{7}$ & 67 & Ca. pancreas & $\mathrm{O}$ & $11 / 18 / 44$ & 9.1 & 15.8 & 281 & 91 & 9 & 25 \\
\hline 12 & C. A. & $q$ & 71 & Ca. pancreas & C & $1 / 18 / 48$ & 15.6 & 27.9 & 188 & 82 & 18 & 34 \\
\hline 13 & E. B. & $\sigma^{7}$ & 65 & Ca. pancreas & A & $5 / 17 / 47$ & 16.8 & 31.0 & 167 & 85 & 15 & 25 \\
\hline 14 & S. B. & $\sigma^{\pi}$ & 55 & Ca. C.B.D. & 0 & $10 / 9 / 44$ & 8.0 & 15.1 & 282 & 80 & 20 & 56 \\
\hline 15 & E. C. & 9 & 62 & Ca. G.B. & O & $6 / 14 / 47$ & 15.3 & 26.0 & 364 & 75 & 25 & 91 \\
\hline 16 & C. C. & $\sigma^{7}$ & 75 & Ca. liver & 0 & $4 / 6 / 47$ & 0.1 & 0.3 & 331 & 74 & 26 & 86 \\
\hline 17 & C. C. & $\sigma^{x}$ & 56 & Ca. pancreas & O & $9 / 24 / 47$ & 14.8 & 28.0 & 282 & 62 & 38 & 107 \\
\hline 18 & A. D. & ه & 54 & Ca. body pancreas & 0 & $2 / 7 / 47$ & 0.1 & 0.4 & 66 & 81 & 19 & 12.5 \\
\hline 19 & H. E. & $\sigma^{\pi}$ & 67 & Ca. pancreas & A & $12 / 20 / 44$ & 28.5 & 43.0 & 217 & 74 & 26 & 56.5 \\
\hline
\end{tabular}


TABLE $\nabla$-Continued

\begin{tabular}{|c|c|c|c|c|c|c|c|c|c|c|c|c|}
\hline \multirow{2}{*}{$\begin{array}{l}\text { Case } \\
\text { no. }\end{array}$} & \multirow{2}{*}{ Initials } & \multirow{2}{*}{ Sex } & \multirow{2}{*}{ Age } & \multirow{2}{*}{ Diagnosis } & \multirow{2}{*}{$\begin{array}{c}\text { Diag- } \\
\text { nobis } \\
\text { by* }\end{array}$} & \multirow{2}{*}{$\begin{array}{l}\text { Date of } \\
\text { determi- } \\
\text { nation }\end{array}$} & \multicolumn{2}{|c|}{ SBt } & \multirow{2}{*}{$\underset{\gamma / 24 \mathrm{hrs}}{\operatorname{UCP}}$} & \multirow{2}{*}{$\underset{I}{P e r}$ cent } & \multirow{2}{*}{$\begin{array}{c}\text { Per cent } \\
\text { III }\end{array}$} & \multirow{2}{*}{$\begin{array}{l}\gamma \text { III/ } \\
24 \text { hrs. }\end{array}$} \\
\hline & & & & & & & $1^{\prime}$ & $\mathbf{T}$ & & & & \\
\hline 20 & M. E. & $0^{x}$ & & Ca. pancreas & 0 & $6 / 18 / 47$ & 9.0 & 15.8 & 443 & 71 & 29 & 128 \\
\hline 21 & A. $F$. & $\sigma^{7}$ & & Ca. C.B.D. & 0 & $10 / 17 / 47$ & & & 294 & 70 & 30 & 88 \\
\hline 22 & P. G. & $\sigma^{7}$ & 74 & Ca. pancreas & C & $8 / 23 / 47$ & 24.2 & 42.1 & 198 & 80 & 20 & 39 \\
\hline 23 & H. G. & $\sigma^{7}$ & 65 & Ca. liver & o & $2 / 27 / 47$ & & & 127 & 69 & 31 & 39 \\
\hline 24 & N. H. & $\sigma^{7}$ & 21 & Ca. liver & 0 & $6 / 30 / 47$ & 0.1 & 0.5 & 79 & 68 & 32 & 25 \\
\hline 25 & L. H. & $0^{7}$ & 69 & Ca. C.B.D. & A & $10 / 21 / 47$ & 7.8 & 14.5 & 177 & 77 & 23 & 41 \\
\hline 26 & R. J. & 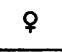 & 25 & Ca. pancreas & 0 & $10 / 20 / 47$ & 6.3 & 11.1 & 242 & 72 & 28 & 68 \\
\hline 27 & A. J. & $\sigma^{7}$ & 45 & Ca. liver & 0 & $4 / 24 / 46$ & 0.1 & 0.9 & 61 & 71 & 29 & 18 \\
\hline 28 & H. J. & q & 66 & Ca. C.B.D. & A & $8 / 13 / 46$ & 0.2 & 0.4 & 280 & 74 & 26 & 73 \\
\hline 29 & M. J. & \& & 56 & Ca. C.B.D. & C & $3 / 3 / 48$ & 2.7 & 3.8 & 149 & 72 & 28 & 42 \\
\hline 30 & S. K. & $\sigma^{\prime \prime}$ & 73 & Ca. liver & C & $9 / 30 / 46$ & 16.0 & 30.0 & 297 & 81 & 19 & 56.5 \\
\hline 31 & W. R. & $\sigma^{x}$ & 70 & Ca. C.B.D. & 0 & $2 / 1 / 46$ & 6.6 & 9.8 & 272 & 77 & 23 & 62.5 \\
\hline 32 & F. U. & $\sigma^{7}$ & 67 & Ca. pancreas & C & $2 / 18 / 48$ & 10.0 & 16.5 & 190 & 78 & 22 & 42 \\
\hline 33 & C. W. & 8 & 58 & Ca. liver & 0 & $7 / 13 / 46$ & 0.1 & 0.8 & 137 & 84 & 16 & 22 \\
\hline 34 & L. W. & 9 & 61 & Ca. C.B.D. & $\mathbf{O}$ & $3 / 26 / 47$ & 8.7 & 14.5 & 214 & 70 、 & 30 & 64 \\
\hline 35 & J. W. & $\sigma^{\pi}$ & 70 & Ca. head pancreas & 0 & $3 / 2 / 46$ & 4.6 & 8.7 & 314 & 80 & 20 & 63 \\
\hline 36 & H. K. & $\sigma^{\prime}$ & 65 & Ca. bile ducts & 0 & $2 / 4 / 47$ & 13.7 & 24.0 & 204 & 75 & 25 & 82 \\
\hline 37 & E. J. & $\sigma^{7}$ & 60 & Adenoca of ampulla & 0 & $8 / 14 / 47$ & 5.6 & 12.2 & 208 & 71 & 29 & 71 \\
\hline 38 & N.P. & $\sigma^{\top}$ & 60 & Ca. pancreas & $\mathbf{0}$ & $5 / 10 / 47$ & 0.4 & 0.9 & 113 & 79 & 21 & 24 \\
\hline 39 & C. A. & $\&$ & 68 & Ca. bile ducts & $\mathbf{O}$ & $4 / 9 / 48$ & 3.6 & 6.4 & 175 & 70 & 30 & 53 \\
\hline 40 & R. S. & 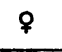 & 53 & Ca. bile ducts & $\mathbf{C}$ & $7 / 10 / 48$ & 0.2 & 1.1 & 249 & 81 & 19 & 47 \\
\hline 41 & B. W. & 9 & 21 & Ca. bile ducts & A & $1 / 30 / 47$ & 5.6 & 10.2 & 300 & 74 & 26 & 79 \\
\hline
\end{tabular}

series, it was noted that $31 \gamma$ was two standard deviations above the mean for the normal group. Thus it is evident that there may be a marked increase of one isomer, even though, percentagewise, the other one is preponderant.

Tables V and VI include the data for the biliary tract cancer and the calculous groups respectively. Two exceptional cases included in Table VI deserve individual consideration. Both of these exhibited considerable increases of type III isomer in contradistinction to the other members of the group, in which the increase was mainly of type I. In both, however, there were prominent features serving to distinguish them in other respects as well. In Case 2, gallstones were found in a large sub-hepatic pocket resembling an abscess; the gall bladder and common duct were not identified and the surgeon believed that there had been a severe inflammation with considerable "breaking down of tissue." The spleen, which was removed, weighed $1270 \mathrm{gm}$., and was diagnosed as splenic hyperplasia or Banti's disease; liver biopsy revealed a definite early cirrhosis. It was impossible to obtain a history of alcoholism or other chemical exposure which might have explained the excessive type III coproporphyrin excretion in this case. The possibility of endogenous chemical intoxication is considered because of the above operative findings.

In Case 12, Table VI, necropsy revealed miliary 
tuberculosis. The possible relationship of this condition to an excessive type III coproporphyrin excretion is not clear and is receiving further study. Again one must consider an endogenous chemical intoxication, due to extensive necrosis, as the important factor.

A third case, not included in the tables, and which we have not been able to classify, was that of an aeronautical engineer, a male, 47 years of age, who was conducting research at very low temperatures. In fact, 24 hours before the onset of his illness, he had spent an hour and a quarter in a cold chamber at $-60^{\circ} \mathrm{F}$, wearing a suit specially designed for high-altitude flying. The temperature of his skin, measured by means of a thermocouple, fell to as low as $84^{\circ} \mathrm{F}$ during the latter part of the experiment. He felt fairly well until the next day when he noticed marked aching in the muscles. This persisted and the next day his temperature rose to $103^{\circ} \mathrm{C}$. Two days later he became jaundiced; the urine was dark and the stools light. The jaundice became more marked and persisted about two weeks, the maximum serum bilirubin being $6.8 \mathrm{mg}$. per $100 \mathrm{cc}$., of which $3.7 \mathrm{mg}$. was the prompt direct (one minute) type. The cephalin cholesterol flocculation test was 3 plus. The 24 hour urine urobilinogen was $113 \mathrm{mg}$. The UCP was $270 \gamma / 24$ hours of which 90 per cent was the

TABLE VI

$U C P$ in cases of common duct stone

\begin{tabular}{|c|c|c|c|c|c|c|c|c|c|c|c|}
\hline \multirow{2}{*}{ Case no. } & \multirow{2}{*}{ Initials } & \multirow{2}{*}{ Sex } & \multirow{2}{*}{ Age } & \multirow{2}{*}{ Date } & \multicolumn{2}{|c|}{$\mathrm{SB}^{*}$} & \multirow{2}{*}{$\underset{\gamma / 24 \mathrm{hrs} .}{\mathrm{UCP}}$} & \multirow{2}{*}{$\underset{I}{\text { Per cent }}$} & \multirow{2}{*}{$\begin{array}{l}\text { Per cent } \\
\text { III }\end{array}$} & \multirow{2}{*}{$\begin{array}{l}\gamma \text { III/ } \\
24 \text { hrs. }\end{array}$} & \multirow{2}{*}{ 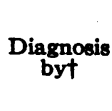 } \\
\hline & & & & & $1^{\prime}$ & $\mathbf{T}$ & & & & & \\
\hline 1 & M. S. & \% & 70 & $4 / 5 / 43$ & 5.8 & 8.1 & 230 & 88 & 12 & 28 & O \\
\hline 2 & C. $\mathrm{M}$. & 9 & 46 & $8 / 18 / 44$ & 4.4 & 7.4 & 260 & 35 & 65 & 169 & 0 \\
\hline 3 & M. R. & q & 32 & $8 / 28 / 44$ & 2.7 & 4.5 & 120 & & & & 0 \\
\hline 4 & H. P. & \% & 50 & $\begin{array}{l}8 / 7 / 46 \\
5 / 5 / 44\end{array}$ & $\begin{array}{r}0.9 \\
13.0\end{array}$ & $\begin{array}{r}1.7 \\
16.3\end{array}$ & $\begin{array}{l}183 \\
330\end{array}$ & 87 & 13 & 24 & 0 \\
\hline 5 & L. C. & \% & 78 & $1 / 13 / 47$ & 0.3 & 1.5 & 139 & & & & C \\
\hline 6 & H. B. & $\sigma^{7}$ & 46 & $11 / 7 / 44$ & 0.4 & 1.2 & 230 & 93 & 7 & 16 & C \\
\hline 7 & J. R. & $\sigma^{7}$ & 58 & $11 / 7 / 44$ & & & 202 & 87 & 13 & 26 & C \\
\hline 8 & E. S. & $\%$ & 37 & $12 / 15 / 45$ & 2.3 & 4.8 & 175 & & & & 0 \\
\hline 9 & A. $\mathbf{M}$. & $\sigma^{7}$ & 51 & $\begin{array}{l}9 / 16 / 46 \\
9 / 17 / 46 \\
9 / 18 / 46 \\
9 / 19 / 46 \\
9 / 20 / 46 \\
9 / 21 / 46 \\
9 / 22 / 46 \\
9 / 23 / 46\end{array}$ & . & 3.9 & $\begin{array}{l}325 \\
302 \\
330 \\
344 \\
264 \\
199 \\
152 \\
109\end{array}$ & 92 & 8 & 26 & 0 \\
\hline 10 & M. R. & q & 62 & $\begin{array}{l}6 / 25 / 46 \\
6 / 26 / 46 \\
6 / 27 / 46 \\
6 / 28 / 46 \\
6 / 29 / 46 \\
7 / 1 / 46 \\
7 / 3 / 46 \\
7 / 7 / 46\end{array}$ & $\begin{array}{l}8.9 \\
3.5\end{array}$ & $\begin{array}{r}14.2 \\
7.2\end{array}$ & $\begin{array}{l}509 \\
223 \\
216 \\
206 \\
180 \\
419 \\
218 \\
238\end{array}$ & $\begin{array}{l}95 \\
92\end{array}$ & $\begin{array}{l}5 \\
8\end{array}$ & $\begin{array}{l}25 \\
17\end{array}$ & 0 \\
\hline 11 & B. $\mathbf{S}$. & $\sigma^{7}$ & 54 & $4 / 2 / 46$ & 0.3 & 1.0 & 248 & 84 & 16 & 40 & C \\
\hline 12 & F. S. & $\sigma^{7}$ & 71 & $\begin{array}{l}5 / 23 / 44 \\
5 / 30 / 44\end{array}$ & 4.3 & 4.9 & $\begin{array}{l}180 \\
184\end{array}$ & 17 & 83 & 149 & $\mathbf{A}$ \\
\hline
\end{tabular}

* SB = serum bilirubin in $† A=$ autopsy mg. per $100 \mathrm{cc} . \quad \mathrm{O}=$ operation

$1^{\prime}=$ prompt direct

$\mathrm{C}=$ clinical study only

$T=$ Total 
TABLE vI-Continued

\begin{tabular}{|c|c|c|c|c|c|c|c|c|c|c|c|}
\hline \multirow{2}{*}{ Case no. } & \multirow{2}{*}{ Initials } & \multirow{2}{*}{ Sex } & \multirow{2}{*}{ Age } & \multirow{2}{*}{ Date } & \multicolumn{2}{|c|}{$\mathrm{SB}^{*}$} & \multirow{2}{*}{$\underset{\gamma / 24 \mathrm{hrs} .}{\mathrm{UCP}}$} & \multirow{2}{*}{$\underset{I}{P e r}$ cent } & \multirow{2}{*}{$\begin{array}{c}\text { Per cent } \\
\text { III }\end{array}$} & \multirow{2}{*}{$\begin{array}{l}\gamma \mathrm{III/} \\
24 \text { hrs. }\end{array}$} & \multirow{2}{*}{$\underset{\text { byt }}{\text { Diagnosis }}$} \\
\hline & & & & & $1^{\prime}$ & $\mathbf{T}$ & & & & & \\
\hline 13 & J. M. & $\sigma^{7}$ & 72 & $\begin{array}{l}9 / 17 / 47 \\
9 / 18 / 47 \\
9 / 20 / 47 \\
9 / 21 / 47\end{array}$ & 4.5 & 10.0 & $\begin{array}{l}575 \\
512 \\
263 \\
262\end{array}$ & $\begin{array}{l}83 \\
82 \\
85\end{array}$ & $\begin{array}{l}17 \\
18 \\
15\end{array}$ & $\begin{array}{l}97 \\
92 \\
39\end{array}$ & 0 \\
\hline 14 & M. S. & 9 & 59 & $1 / 25 / 48$ & 1.9 & 3.8 & 117 & 90 & 10 & 12 & 0 \\
\hline 15 & R. B. & 9 & 61 & $1 / 25 / 48$ & 0.9 & 1.6 & 115 & 88 & 12 & 14 & 0 \\
\hline 16 & F. G. & $0^{x}$ & 81 & $4 / 29 / 47$ & 2.2 & 3.7 & 238 & 93 & 7 & 17 & A \\
\hline 17 & J. W. & $\sigma^{7}$ & 72 & $7 / 9 / 46$ & 0.4 & 1.4 & 89 & 91 & 9 & 8 & 0 \\
\hline 18 & J. J. & $0^{x}$ & 58 & $3 / 3 / 46$ & 3.1 & 6.5 & 159 & 81 & 19 & 30 & 0 \\
\hline 19 & A. $\mathrm{H}$. & $q$ & 74 & $9 / 3 / 46$ & 8.4 & 12.9 & 214 & 77 & 23 & 49 & 0 \\
\hline 20 & M. H. & $0^{7}$ & 46 & $12 / 9 / 45$ & 0.2 & 2.1 & 172 & 85 & 15 & 26 & C \\
\hline 21 & M. C. & $q$ & 30 & $5 / 5 / 46$ & 0.2 & 1.7 & 67 & 82 & 18 & 12 & C \\
\hline 22 & H. H. & 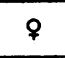 & 37 & $7 / 8 / 46$ & 0.9 & 2.6 & 116 & 86 & 14 & 16 & 0 \\
\hline 23 & C. F. & $q$ & 68 & $1 / 8 / 47$ & 1.2 & 3.0 & 210 & 91 & 9 & 19 & 0 \\
\hline 24 & I. R. & $q$ & 40 & $5 / 12 / 47$ & 0.1 & 0.4 & 64 & 79 & 21 & 13 & 0 \\
\hline 25 & A. F. & $q$ & 58 & $9 / 18 / 47$ & 0.2 & 1.1 & 116 & 83 & 17 & 20 & $\mathrm{C}$ \\
\hline 26 & I. M. & $q$ & 66 & $4 / 4 / 48$ & 0.3 & 1.3 & 67 & 79 & 21 & 14 & 0 \\
\hline 27 & E. M. & 9 & 38 & $1 / 7 / 48$ & 0.1 & 0.9 & 108 & 80 & 20 & 22 & C \\
\hline 28 & K. H. & $\sigma^{x}$ & 71 & $4 / 12 / 48$ & 0.2 & 1.1 & 105 & 90 & 10 & 11 & C \\
\hline 29 & C. H. & $\%$ & 73 & $2 / 13 / 48$ & 2.5 & 4.9 & 186 & 94 & 6 & 11 & 0 \\
\hline 30 & L. C. & $0^{7}$ & 41 & $11 / 15 / 48$ & 0.4 & 1.4 & 138 & 88 & 12 & 17 & 0 \\
\hline
\end{tabular}

TABLE VII

UCP and isomer distribution in Case 49 (Figure 2)

\begin{tabular}{lcc}
$\begin{array}{c}\text { Date } \\
2-25-47\end{array}$ & $\begin{array}{c}\text { UCP in } \\
\gamma / 24 \text { hrs. }\end{array}$ & $\begin{array}{c}\text { Per cent } \\
\text { Type I }\end{array}$ \\
$3-7$ & 445 & 90 \\
$3-15$ & 593 & \\
$3-25$ & 554 & \\
$4-2$ & 400 & \\
$4-8$ & 413 & \\
$4-15$ & 302 & \\
$4-22$ & 275 & 93 \\
$4-29$ & 201 & \\
$5-6$ & 234 & \\
$5-13$ & 188 & \\
$5-20$ & 225 & \\
$6-17$ & 270 & \\
$8-5$ & 259 & \\
$8-14$ & 122 & \\
$1-29-48$ & 253 & \\
$2-8$ & 200 & \\
$2-8$ & 232 & 94 \\
$7-16$ & $290^{*}$ & \\
$10-29$ & 130 & 95 \\
\hline
\end{tabular}

* Feces-amount for one day. type III isomer. The attack was relatively mild and the patient felt quite well six weeks later. This would in all likelihood have been accepted as an episode of sporadic infectious hepatitis if it were not for the curious circumstances at the outset, coupled with the result of the porphyrin determination. The former might be regarded simply as a precipitating factor, but it was then found that there had been considerable alcoholism in the weeks or months preceding the onset of the jaundice, also that there had been moderate exposure to a number of chemicals and heavy metals in connection with the patient's research. Furthermore, the excessive type III coproporphyrin excretion persisted long after the attack of jaundice which has just been described. On March 8, 1946, nearly two years later, the UCP was $208 \gamma / 24$ hours with 65 per cent type III ; on August 14, 1946, it was $187 \gamma$, 
and on November 23, 1946, $175 \gamma$. Thus, while it was impossible to classify this case, it appeared reasonable to believe that it was more likely due to extrinsic chemical and possibly physical factors, and less likely to an infectious hepatitis, although a combination of chemical and viral factors is a distinct possibility.

\section{DISCUSSION}

The present results reveal that the urinary coproporphyrin is quite uniformly increased in regurgitation jaundice, whether due to biliary obstruction or to parenchymal hepatic disease. Further study is necessary to determine if this is due only to regurgitation of bile into the blood stream, or to hepatocellular functional impairment, or to a combination. The persistent and often marked elevation of the urinary coproporphyrin long after the disappearance of jaundice points toward an hepatocellular or retention, rather than a cholangiolar or regurgitation factor. The elevated values in obstructive jaundice, however, are perhaps indicative of the latter, particularly inasmuch as they were observed in relatively early cases before one would anticipate significant hepatocellular functional impairment. Van den Bergh (23) was impressed by the coproporphyrinemia and increased coproporphyrinuria in mechanical jaundice, and ascribed them to regurgitation of bile into the blood. Gonzalez-Oddone, working in this laboratory, has observed ${ }^{5}$ that intravenously injected coproporphyrin appears in the thoracic duct lymph of dogs having ligated common bile ducts, in this respect behaving like injected bromsulfalein (24). Thus it appears that, in cases of jaundice, the coproporphyrin may appear in the urine in excess as a result either of hepatocellular or cholangiolar impairment, in the first instance probably being retained and in the second, regurgitated from the intrahepatic biliary system into the blood. The fact that the highest values are more likely to be encountered in jaundice due to hepatitis or cirrhosis may indicate a combination of these factors in such cases. This is quite in harmony with the belief that in hepatitis, there is both hepatocellular and cholangiolar injury, varying in severity in different instances and at different stages in the same instance (25).

It is appropriate to ask whether the increased

ธ Unpublished observation. amounts of coproporphyrin I in the urine of the present series of cases represents actual overproduction of this porphyrin, or merely a diversion of that which would normally be excreted in the bile and thence in the feces. There is actually no evidence of over-production. It has already been seen that the factors of retention and regurgitation are probably operative in reducing the biliary excretion of coproporphyrin and increasing its excretion in the urine. The amounts in the urine in these cases do not exceed those of the normal feces in 24 hours. Thus the evidence so far available indicates simple diversion rather than over-production, at least in the majority of cases in which type $I$ is preponderant in the urine. This may be true as well for other conditions in which increased amounts of coproporphyrin I are found in the urine. Simultaneous studies of fecal and urinary excretion are needed, however, before the question can be answered with certainty. The available evidence at the present time $(4,5)$ indicates that there are but two conditions under which an overproduction of the type I isomer may be anticipated: (1) porphyria, a constitutional metabolic fault; (2) increased erythropoietic activity following increased blood destruction or blood loss. In the case of the type III isomer, it is clear that there is often marked overproduction and increased excretion from various causes (5).

It appears unlikely that a determination of the total urinary coproporphyrin will frequently be of value in the distinction of parenchymal jaundice from jaundice due to extrahepatic biliary obstruction. Careful study of the data obtained in the present study reveals considerable overlapping of values at various levels of icterus due to biliary obstruction as compared with diffuse liver injury. In Figure 4 the values for UCP in the cancerous, calculous, and hepatitis-cirrhosis groups are plotted against the values for total bilirubin. The data for the cases of cirrhosis included in this figure are considered in more detail in the subsequent paper of this series. It is seen in Figure 4 that while there is no distinct cleavage between the hepatitis-cirrhosis and the other groups, the higher values with lesser degrees of jaundice are more characteristic of the former. It appears from these data that values of $250 \gamma / 24$ hours, or higher, with total serum bilirubins less than $6.0 \mathrm{mg}$., as enclosed 


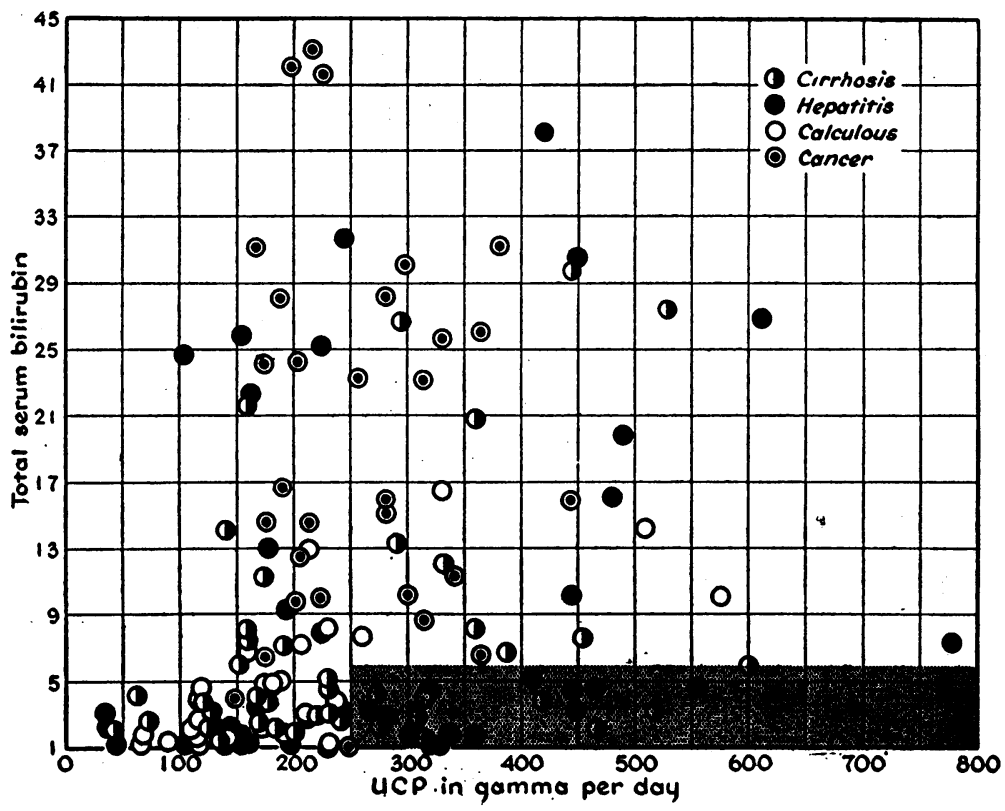

Fig. 4. UCP and Total Serum Bilirubin in Cases of Billary Tract Cancer, Common Duct Calculus, Infectious Hepatitis, and Cirrhosis

in the shaded area in Figure 4, are much more likely to be associated with hepatitis or cirrhosis, than with extrahepatic biliary obstruction.

Insofar as hepatitis is concerned, the determination of the UCP is of more value in detecting residual hepatic functional impairment at varying intervals after the disappearance of jaundice. In the present series 45 of 95 cases exhibited elevated values at varying intervals after disappearance of jaundice.

In Table VIII, the cases for which data were given in Table II, are subdivided as to whether the increase or lack of increase of the UCP was associated with other abnormalities, either symptomatic, physical or laboratory in character. It is seen that the UCP was elevated in 11 instances (groups $2 a$ and $2 c$ ) in which the other laboratory findings were normal. Five of these had significant symptoms or physical findings and six did not. The largest number of cases were in group $2 \mathrm{~b}$ in which there were symptoms or physical findings together with other abnormal laboratory data. It should be noted that in a number of instances in this group the other laboratory abnormalities

TABLE VIII

Groups with presence or absence of symptoms,* physical findings,* or abnormal laboratory data

1. Symptoms or physical findings without abnormal laboratory findings

2. UCP $>100 \gamma / 24$ hr. (abnormal)

a. Without symptoms or abnormal physical findings and without other laboratory abnormalities

b. With symptoms or physical findings and with other laboratory abnormalities

c. With symptoms or physical findings but without other abnormal laboratory data

d. With other abnormal laboratory data, but without symptoms or physical findings

3. UCP $<100 \gamma / 24 \mathrm{hr}$. (normal), with other laboratory abnormalities, and with or without physical findings

* Symptoms.> I, liver enl. > $1 \mathrm{~cm}$. liver tenderness + or greater (see key, Table II).
Case nos. (as in Table II)

$3,19,29,35,37,59$

$4,11,15,38,49,61$

$5,6,7,9,11,12,14,16,17,18$

$21,22,23,27,28,30,32,33,34$,

$40,42,43,44,45,46,48,49,51$,
$52,53,54,56,57,59,60,62$

$8,10,26,31,36$

39,41

$13,20,24,47,50,55$

6
Total 
were isolated ; thus, in Cases 7, 9, 18, 21, 23, 34, and 59 , the only abnormality in addition to the excessive UCP, was an elevated urine Ehrlich reaction; while in Cases 33, 36, 43 and 53 the only other abnormality was in the serum bilirubin level.

It was of particular interest to compare the UCP and the bromsulfalein retention, especially in those cases in which other findings were borderline. As noted in Table II, the bromsulfalein test was carried out 53 times in 43 cases. The UCP value corresponding in time with these determinations, was significantly elevated $(>100 \gamma / 24$ hours) in 22 instances in which the bromsulfalein retention did not exceed 5 per cent; conversely, there was but one instance in which the opposite was true. This was Case 13 in Table II, in which the bromsulfalein retention was 8 per cent and the UCP $92 \gamma / 24$ hours. Insofar as the UCP and cephalin flocculation tests are concerned, inspection of Table II reveals a negative flocculation in a number of instances in which the UCP was significantly increased; none are found in which the reverse was true.

At present there is no way of determining whether residual functional impairment is synonymous with persistent activity of a virus hepatitis.
From a practical standpoint, at any rate, it is probably wise to advise caution as to unusual activity, strain, fatigue, alcohol, etc., at least until the evidence of residual impairment has disappeared. Case 49 in Table II is an example of this problem. Further data for this case are given in Figure 2 and Table VII. This individual was permitted to resume his normal occupation in spite of persistent elevation of the UCP, but at the same time he was enjoined to avoid undue fatigue, irregular hours of sleep and alcohol. One of the problems of the recovery state of hepatitis has been that the individual may complain of persistent weakness and fatigue even though the results of various liver function tests are normal or borderline. In a number of such instances included in the present study, the elevated urinary coproporphyrin gave indication of residual activity or impairment, and appeared to be correlated with the symptoms of fatigue, weakness or nervousness. Conversely, however, we have observed several individuals complaining of one or more of these symptoms yet having normal porphyrin values in addition to normal composite liver function studies. In such instances it has been impossible to decide with certainty whether the symptoms were on a psychic

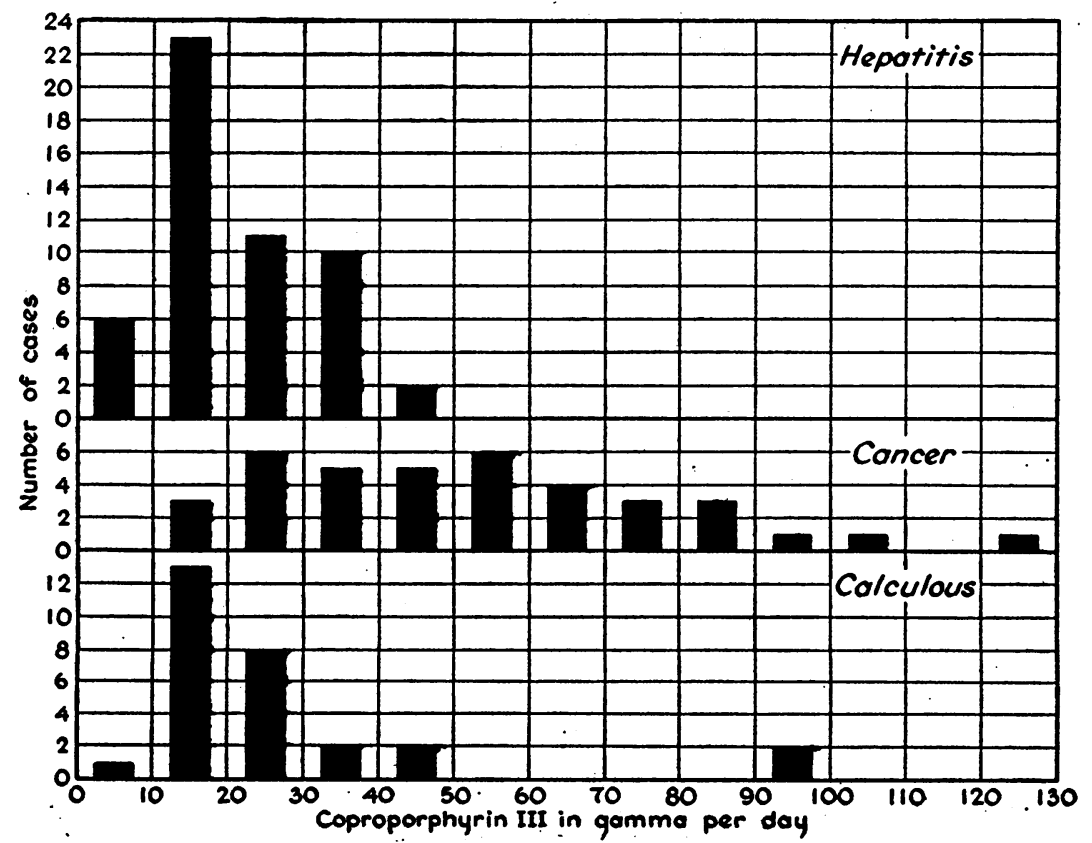

Fig. 5. Frequency Distribution of Values for Urinary Coproporphyrin III in Cases of Hepatitis, Bintary Tract Cancer, and Common Duct Calculus 
basis or were in reality due to residual hepatic impairment. Additional studies, including exercise tolerance with relation to coproporphyrin excretion, are desirable in order to determine the degree of assistance one may expect from this determination.

From the present results it is evident that the increase in UCP in hepatitis and mechanical jaundice is due in the main to increased excretion of the type $I$ isomer. Inspection of the data in Tables III, IV, V and VI, reveals, however, that in some instances the amount of type III isomer exceeds the normal upper limit of $34 \gamma / 24$ hours reported previously (14). In the hepatitis and infectious mononucleosis groups there are few of these and the excess is slight, probably within the limit of error of the differential precipitation method (12, 13). The two outstanding exceptions were cases in the calculous group which have already been referred to ; one of these had a necrotic abscess with marked splenomegaly, and the other had miliary tuberculosis. In one additional instance (Case 13 in Table VI) an unexplained absolute increase of type III coproporphyrin is noted, comprising, however, but 17-18 per cent of the total UCP. In the cancer group, there are quite a number of cases having considerable excesses of type III isomer even though type $I$ is clearly preponderant in each instance. Frequency distribution curves for the three groups are shown in Figure 5. Several cases, already discussed, have been omitted in the preparation of this figure, because of significant peculiarities believed to place them in separate categories. These cases are numbers 51 in Table II, 2 and 12 in Table VI. Figure 5 reveals the relative frequency of increased coproporphyrin III excretion in the cancer group. Nineteen of 39 cases in this group had values above $50 \mu \mathrm{g}$. in 24 hours, while all of the 40 in the hepatitis group were below this level. Thus it is evident that the patients with cancer of the biliary tract or liver vary significantly in the composite, from the other groups, and especially from the hepatitis group, in respect to porphyrin metabolism. It appears that an absolute increase of the type III isomer greater than $50 \gamma / 24$-hour urine sample, favors the diagnosis of cancer rather than hepatitis, and is much more likely to be encountered with cancer than with calculus, in the presence of regurgitation jaundice. The reason for this difference is not clear, but the possibility may be entertained of an endogenous chemical intoxication, from necrotic or abnormal cells. It is recognized too, that a constitutional factor cannot be excluded.

\section{SUMMARY AND CONCLUSIONS}

1. The total urinary coproporphyrin (UCP) is regularly increased above the upper limit of normal of $100 \gamma / 24$-hour urine sample, both in infectious hepatitis during the period of jaundice, and in cases of mechanical jaundice. The increase in cases of hepatitis often persists in some measure for considerable periods after the disappearance of jaundice and after the return to the normal range of conventional tests such as bromsulfalein retention and cephalin cholesterol flocculation. In certain instances the increase of the UCP has constituted the only objective evidence of residual hepatic functional impairment.

2. In cases of infectious mononucleosis the UCP is commonly increased, usually in association with other evidence of hepatic functional impairment.

3. Isomer analysis has shown that the increase in UCP in infectious hepatitis, infectious mononucleosis, and mechanical jaundice, is mainly due to the type I isomer. Certain exceptions are discussed and it is shown that in cases of cancer of the pancreas; bile ducts, or liver, the increased UCP, although preponderantly type I, includes an absolute increase of type III with relative frequency. This has not been observed to any significant degree in cases of infectious hepatitis, infectious mononucleosis, or uncomplicated calculous jaundice.

\section{BIBLIOGRAPHY}

1. Garrod, A. E., On haematoporphyrin as a urinary pigment in disease. J. Path. and Bacteriol., 1892, $1,187$.

2. Garrod, A. E., On the urinary pigments in their pathological aspects. Lancet, 1900, 2, 1323.

3. Fischer, H., and Zerweck, W., Zur Kenntnis der natürlichen Porphyrine. V. Über Koproporphyrin im Harn und Serum unter normalen und pathologischen Bedingungen. Ztschr. f.' physiol. Chem., 1924, 132, 12.

4. Dobriner, K., and Rhoads, C. P., The porphyrins in health and disease. Physiol. Rev., 1940, 20, 416.

5. Watson, C. J., and Larson, E. A., The urinary coproporphyrins in health and disease. Physiol. Rev., 1947, 27, 478.

6. Nesbitt, S., and Snell, A. M., Excretion of coproporphyrin in hepatic disease. I. Correlation of 
urinary and fecal excretion with parenchymatous hepatic damage. Arch. Int. Med., 1942, 69, 573.

7. Nesbitt, S., and Snell, A. M., Excretion of coproporphyrin in hepatic disease. II. Urinary and fecal excretion in biliary obstruction. Ibid., 1942, 69, 582.

8. Localio, S. A., Schwartz, M. S., and Gannon, C., The urinary/fecal coproporphyrin ratio in liver disease. J. Clin. Invest., 1941, 20, 7.

9. Watson, C. J., Concerning the naturally occurring porphyrins. I. The isolation of coproporphyrin I from the urine in a case of cincophen cirrhosis. J. Clin. Invest., 1935, 14, 106.

10. Watson, C. J., Concerning the naturally occurring porphyrins. V. Porphyrins of the feces. J. Clin. Invest.; 1937, 16, 383.

11. Dobriner, $K$., The urinary porphyrins in disease. J. Biol. Chem., 1936, 113, 1.

12. Schwartz, S., Hawkinson, V., and Watson, C. J., Quantitative differentiation of minute amounts of the coproporphyrin isomers (I and III) based on fluorescence behavior. Science, 1946, 103, 338.

13. Schwartz, S., Hawkinson, V., Cohen, S., and Watson, C. J., A micromethod for the quantitative determination of the urinary coproporphyrin isomers (I and III). J. Biol. Chem., 1947, 168, 133.

14. Watson, C. J., Hawkinson, V., Schwartz, S., and Sutherland, D., Studies of coproporphyrin. I. The per diem excretion and isomer distribution of coproporphyrin in normal human urine. J. Clin. Invest., 1949, 28, 447.

15. Ducci, H., and Watson, C. J., The quantitative determination of the serum bilirubin with special reference to the prompt-reacting and the chloroformsoluble types. J. Lab. \& Clin. Med., 1945, 30, 293.

16. Mateer, J. G., Baltz, J. I., Marion, D. F., and MacMillan, J. M., Liver function tests; general evaluation of liver function tests and appraisal of comparative sensitivity and reliability of newer tests, with particular emphasis on cephalin-cholesterol flocculation test, intravenous hippuric acid test, and improved bromsulfalein test with new normal standard. J. A. M. A., 1943, 121, 723.

17. Hanger, F. M., The flocculation of cephalin-cholesterol emulsions by pathological sera. Tr. A. Am. Physicians, 1938, 53, 148.

18. Schoenheimer, R., and Sperry, W., A micromethod for the determination of free and combined cholesterol. J. Biol. Chem., 1934, 106, 745.

19. Schwartz, S., Sborov, V., and Watson, C. J., Studies of urobilinogen. IV. The quantitative determination of urobilinogen by means of the Evelyn photoelectric colorimeter. Amer. J. Clin. Path., 1944, 14, 598.

20. Watson, C. J., Schwartz, S., Sborov, V., and Bertie, E., Studies of urobilinogen. V. A simple method for the quantitative recording of the Ehrlich reaction as carried out with urine and feces. Ibid., $1944,14,605$.

21. Watson, C. J., and Hawkinson, V., Studies of urobilinogen. VI. Further experience with the simple quantitative Ehrlich reaction. Corrected calibration of the Evelyn colorimeter with a pontacyl dye mixture in terms of urobilinogen. Am. J. Clin. Path., 1947, 17, 108.

22. Watson, C. J., Schulze, W. M., Hawkinson, V., and Baker, A. B., Coproporphyrinuria (Type III) in acute poliomyelitis. Proc. Soc. Exp. Biol. \& Med., 1947, 64, 73.

23. H. van den Bergh, A. A., Grotepass, W., and Revers, F. E., Beitrag über das Porphyrin in Blut und Galle. Klin. Wchnschr., 1932, 11, 1534.

24. Gonzalez-Oddone, M. V., Bilirubin, bromsulfalein, bile acids, alkaline phosphatase, and cholesterol of thoracic duct lymph in experimental regurgitation jaundice. Proc. Soc. Exp. Biol. \& Med., 1946, 63, 144.

25. Watson, C. J., and Hoffbauer, F. W., Liver function in hepatitis. Ann. Int. Med., 1947, 26, 813.

26. Peterson, R. E., Hepatic dysfunction in infectious mononucleosis; with review of the literature. J. Lab. \& Clin. Med., 1948, 33, 1258. 